\title{
Comparison of Engineered Peptide-Glycosaminoglycan Microfibrous Hybrid Scaffolds for Potential Applications in Cartilage Tissue Regeneration
}

\author{
Steven M. Romanelli, Grant A. Knoll, Anthony M. Santora, Alexandra M. Brown and \\ Ipsita A. Banerjee * \\ Department of Chemistry, Fordham University, 441 East Fordham Road, Bronx, NY 10458, USA; \\ E-Mails: sromanelli@fordham.edu (S.M.R.); gknoll@fordham.edu (G.A.K.); \\ asantorabermudez@fordham.edu (A.M.S.); abrown72@fordham.edu (A.M.B.)
}

* Author to whom correspondence should be addressed; E-Mail: banerjee@fordham.edu; Tel.: +718-817-4445.

Academic Editor: Jingwei Xie

Received: 1 June 2015 / Accepted: 10 July 2015 / Published: 17 July 2015

Abstract: Advances in tissue engineering have enabled the ability to design and fabricate biomaterials at the nanoscale that can actively mimic the natural cellular environment of host tissue. Of all tissues, cartilage remains difficult to regenerate due to its avascular nature. Herein we have developed two new hybrid polypeptide-glycosaminoglycan microfibrous scaffold constructs and compared their abilities to stimulate cell adhesion, proliferation, sulfated proteoglycan synthesis and soluble collagen synthesis when seeded with chondrocytes. Both constructs were designed utilizing self-assembled Fmoc-protected valyl cetylamide nanofibrous templates. The peptide components of the constructs were varied. For Construct I a short segment of dentin sialophosphoprotein followed by Type I collagen were attached to the templates using the layer-by-layer approach. For Construct II, a short peptide segment derived from the integrin subunit of Type II collagen binding protein expressed by chondrocytes was attached to the templates followed by Type II collagen. To both constructs, we then attached the natural polymer N-acetyl glucosamine, chitosan. Subsequently, the glycosaminoglycan chondroitin sulfate was then attached as the final layer. The scaffolds were characterized by Fourier transform infrared spectroscopy (FT-IR), differential scanning calorimetry (DSC), atomic force microscopy and scanning electron microscopy. In vitro culture studies were carried out in the presence of chondrocyte cells for 
both scaffolds and growth morphology was determined through optical microscopy and scanning electron microscopy taken at different magnifications at various days of culture. Cell proliferation studies indicated that while both constructs were biocompatible and supported the growth and adhesion of chondrocytes, Construct II stimulated cell adhesion at higher rates and resulted in the formation of three dimensional cell-scaffold matrices within 24 h. Proteoglycan synthesis, a hallmark of chondrocyte cell differentiation, was also higher for Construct II compared to Construct I. Soluble collagen synthesis was also found to be higher for Construct II. The results of the above studies suggest that scaffolds designed from Construct II be superior for potential applications in cartilage tissue regeneration. The peptide components of the constructs play an important role not only in the mechanical properties in developing the scaffolds but also control cell adhesion, collagen synthesis and proteoglycan synthesis capabilities.

Keywords: cartilage; scaffolds; collagen; chitosan; fibers

\section{Introduction}

Recent advances in biomaterial synthesis coupled with improvements in tissue engineering (TE) techniques have resulted in the development of implantable materials for bone, bladder, skin and blood vessel regeneration [1]. Such materials have shown promise as alternative means to repair damaged tissue through the utilization of biological or synthetic materials that stimulate cellular and tissue growth $[2,3]$. TE strategies typically rely on cell-seeded, three-dimensional (3D) biocompatible scaffolds that mimic the extracellular matrix (ECM) and are capable of assembling into functional structures suitable for non-invasive implantation and faster recovery time as compared to traditional surgery $[4,5]$.

In the realm of TE however, cartilage regeneration has remained relatively elusive due to its avascular nature and inability to mount an effective healing response [6]. Cartilage is a specialized tissue which functions to enable stable and smooth movements of joint surfaces and allows for the dissipation of mechanical loads under physiological conditions [7]. Degradation of cartilage, specifically articular cartilage on the surface of joints is correlated with age-related changes in chondrocyte function [8]. Focal chondral defects can be painful or disabling and may predispose patients for osteoarthritis $[9,10]$. Traditionally, standard healing techniques have aimed at inducing marrow stimulation and incorporating allografts or autografts, however, these procedures often fail and result in inferior cartilage [11-13]. Furthermore, most surgical interventions have been directed at treating clinical symptoms such as pain relief rather than focusing on the regeneration of native cartilage [14].

Advances in cartilage TE have relied upon the use of 3D scaffolds for necessary support which mimic the ECM of chondrocytes to provide an optimal environment for cellular proliferation [15]. The native chondrocyte ECM is a highly hydrated environment complexed with various non-collagenous and collagenous fibers, proteins, glycosaminoglycans (GAGs) and proteoglycans [16]. Attempts to mimic this environment by using hydrogel materials has shown promise in restoring functionally competent cartilage because of the inherent cross-linked hydrogel polymer networks which facilitate efficient transport of nutrients and actively form physical environments similar to that of articular cartilage [17]. Natural 
hydrogel polymers include chitosan, collagen, hyaluronic acid, gelatin and alginate, whereas synthetic polymers encompass poly(glycolic acid) (PGA), poly(lactic acid) (PLA), poly(ethylene oxide) (PEO), poly(vinyl alcohol) (PVA), poly(acrylic acid) (PAA) and their copolymers [18-24]. Typically, such hydrogel materials can be functionalized or assembled with specific functional groups to impart enhanced biocompatible properties. For example, esterification of hyaluronic acid with benzoic acid results in a water-insoluble scaffold (HYAFF 11) which has been used clinically to treat chronic symptomatic defects in joint surfaces [25,26]. In another study, dicarboxymethyl chitosan conjugated with bone morphogenetic protein-7 demonstrated repair of cartilage lesions [27]. Many studies have utilized combinations of both natural and synthetic polymers. For example, poly(lactic-co-glycolic acid)gelatin/chondroitin/hyaluronate (PLGA-GCH) gels demonstrated significantly increased mesenchymal stem cell proliferation and GAG synthesis as compared to PLGA gels alone [28,29].

Recent work utilizing peptide amphiphile derived hydrogels has illustrated their ability to self-assemble into well-defined nanofibers by relatively facile means [30]. These materials can be manipulated through varying the sequence length or composition of the peptide segment as well as controlling hydrogen bonding within the secondary structure of the peptide to fine tune its structure at the nanoscale [31]. For example, RGD (arginine-glycine-aspartate) adhesion peptide sequences incorporated within peptide-based hydrogels have been shown to induce cellular binding, migration, proliferation and growth in fibroblast, endothelial and chondrocyte cell lines [32-34]. Furthermore, fluorenylmethyloxycarbonyl (Fmoc) protecting groups on peptides have been shown to form gels due to $\pi-\pi$ stacking interactions, electrostatic interactions and hydrogen bonding, which improve the stability of the material [35]. Such materials are also biocompatible and may induce chondrocyte proliferation as indicated in work by Ulijn and colleagues, in which Fmoc-Phe 2 along with Fmoc-Ser, Fmoc-Lys and Fmoc-Asp gels supported the viability of chondrocytes and increased the viability of 3T3 fibroblasts [36]. Additionally, Fmoc-FF and Fmoc-RGD peptide derivatives assembled to form nanofibrous hydrogels capable of promoting adhesion and encapsulation of anchorage-dependent cells for in vitro TE [37].

In previous work, we reported the formation of Fmoc derived peptides covalently linked to cetyl amine (FVC) and demonstrated their ability to form a nanofibrous matrix and support growth and proliferation of mouse pre-osteoblasts [38,39]. Herein, we have developed two new hybrid peptide-glycosaminoglycan based constructs using FVC as a template and examined their ability to promote proliferation and attachment of chondrocytes as well as promote chondrogenesis (Scheme 1). Construct I was assembled via the layer-by-layer assembly technique utilizing template FVC fibers followed by attachment of a short segment of dentin sialophosphoprotein motif (EDPHNEVDGDK) (DSp), Type I collagen (Col-I), chitosan (Ch) and chondroitin sulfate (CS) to form 3D hybrid matrices. In general, the dentin sialophosphoprotein gene, which is found to be expressed in bone and teeth, plays a vital role in dentinogenesis as well as in osteogenesis [40]. Furthermore, it was recently shown that human gingival stem cells (HGSCs) could successfully be differentiated to osteogenic and chondrogenic cells and therefore may provide new strategies in regenerative medicine for cartilage and joint repair [41]. Additionally, it has also been reported that DSp is essential for growth and maintenance of mandibular condylar cartilage [42]. Although it is well known that dentin sialophosphoprotein plays an important role in the mineralization of hard tissues such as bone and teeth, demineralized dentin matrices have been shown to function as efficient scaffolds for cartilage repair $[43,44]$. Moreover, dentin sialophosphoprotein belongs to the family of small integrin binding ligands (SIBLING) which have several factors common 
with matrix extracellular phosphoglycoproteins [45]. It was recently shown that dentin sialophosphoprotein is also expressed in non-mineralized soft tissues and therefore may have additional functions other than mineralization [46]. Thus we hypothesized that incorporation of a segment of dentin sialophosphoprotein may aid in chondrogenesis and cartilage tissue repair. Col-I was incorporated as the third layer. It is well known that Col-I forms densely-packed fibrillar structures that inherently resist stress caused by tension, showing potential as an effective biomaterial for soft tissue regeneration applications [47]. While Col-II is a major component of articular and elastic cartilage, Col-I is a component of fibrocartilage along with Col-II and aggregan and is found in intervertebral disc spaces. Thus we incorporated Col-I into Construct I to examine if it would aid in chondrocyte adhesion and proliferation [48]. As the next component, we added chitosan (Ch). In general, cartilage contains various GAGs rich in $N$-acetyl-glucosamine groups and these groups play a vital role in interactions with growth factors, adhesion proteins and receptors [49]. The glucosamine constituent in Ch is key for the synthesis of proteoglycans to help form the cartilage ECM [50]. Furthermore, the ability of $\mathrm{Ch}$ to form porous, gelatinous structures is advantageous for cell transplantation and tissue regeneration [51]. As the final layer of the scaffold Construct I, we incorporated chondroitin sulfate (CS) which is a structural component of cartilage tissue. In general, GAGs and proteoglycans are found entwined with collagens in the ECM of chondrocytes and thus we chose to incorporate each component such that the final scaffold mimics the ECM of chondrocytes [52,53]. In addition, CS has been shown to have beneficial properties in preventing osteoarthritis by stimulating the metabolic response of the tissue and having anti-inflammatory properties [54,55]. Additionally, CS has been explored as an adhesive agent between scaffold and cartilage defects and has been shown to maintain chondrocyte phenotype, increase type II collagen synthesis and not alter GAG production in native tissue [56].
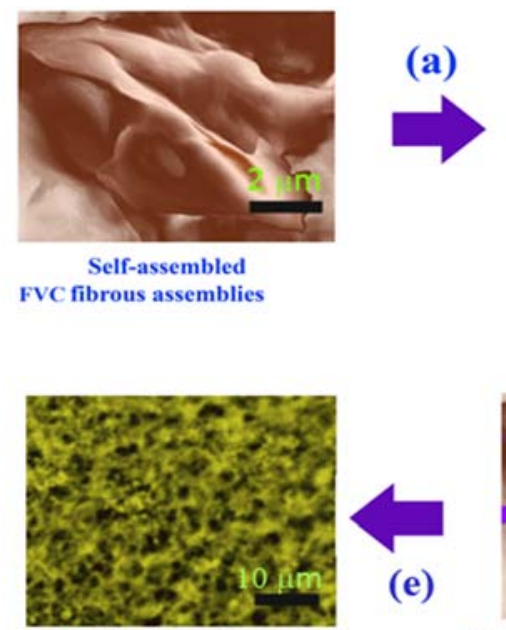

Chondrocyte adhesion and proliferation in scaffold matrices

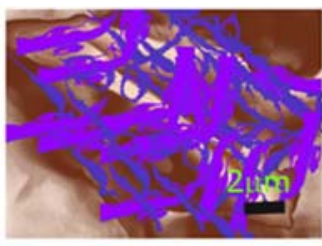

Incorporation of EDPHNEVDGDK(Construet I) KIGFFAH

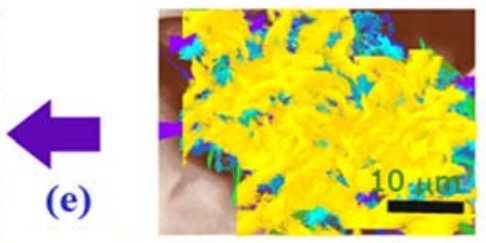

Incorporation of chondroitin sulfate (for both constructs I and II)

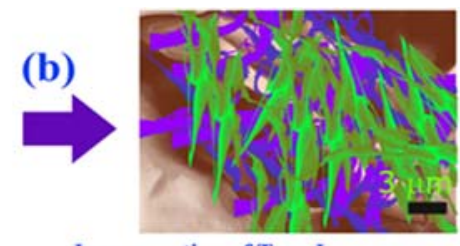

Incorporation of Type I

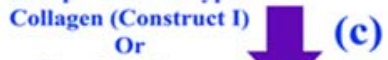
Type II Collagen (Construet II)

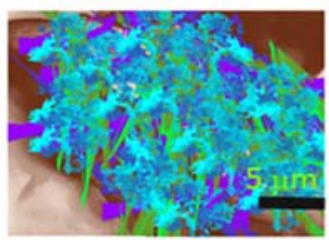

Incoporation of Chitosan (for both construets I and II)

Scheme 1. Scheme of layer-by-layer assembly of Construct I and Construct II. (a) Fmoc-Valyl-Cetylamide (FVC) self-assembled fibrous assemblies incorporated with specific peptide sequence: EDPHNEVDGDK (Construct I) or KLGFFAH (Construct II); (b) Addition of collagen: Type I (Construct I) or Type II (Construct II); (c) Incorporation of chitosan which was consistent across both constructs; (d) Incorporation of chondroitin sulfate which was also consistent for both constructs; (e) Interactions with chondrocytes. 
Because peptide components play a vital role in cartilage tissue regeneration, we also designed a second construct (Construct II) and studied its efficiency as a scaffold by keeping the template, the GAG and the $N$-acetyl-glucosamine components the same as Construct I but by varying the collagen type and the peptide component. For Construct II, to the template FVC assemblies we incorporated a short peptide sequence KLGFFAH (abbreviated as: CP) followed by Type II collagen (Col-II), Ch and CS. It was recently reported that chondrocytes express specific collagen Type II-binding integrin protein. The CP sequence utilized here is a component of the chondrocyte $\alpha-10$ integrin subunit that contains the conserved sequence KLGFFAH that is involved in binding to Col-II [57]. Consequently as the next layer, we incorporated Col-II which is found abundantly in both hyaline and elastic cartilage [58,59]. Col-II is composed of fibrillar chain networks resistant to swelling pressures and has been shown to promote retention of spherically shaped chondrocytes in addition to initiating and maintaining chondrogenesis [60-62]. The final two layers were added in the same order as that of Construct I, namely $\mathrm{Ch}$ and CS to prepare scaffold Construct II.

Thus, we have developed two new hybrid peptide-glycosaminoglycan-based materials in which the peptide components were varied to examine their efficiency as scaffolds for potential applications in cartilage tissue regeneration. We compared the effects of the scaffolds to induce chondrogenesis as well as chondrocyte cell attachment, proliferation, collagen synthesis and growth.

\section{Experimental Section}

\subsection{Materials}

1-Ethyl-3-(3-dimethylaminopropyl) carbodiimide (EDAC), N-hydroxy succinimide (NHS), Bornstein and Traub Type I collagen from calf skin, chitosan (medium molecular weight, containing $75 \%-85 \%$ deacetylated chitin), the mucopolysaccharide chondroitin sulfate A containing $D$-glucuronic acid, $N$-acetylgalactosamine, and sulfate residues in equimolar quantities (from bovine trachea), solvents such as DMF, Picric acid saturated solution (1.3\%), acetic acid, direct red 80, methanol and methylene chloride were purchased from Sigma-Aldrich (St. Louis, MO, USA). Type II collagen lyophilized, derived from bovine nasal cartilage was purchased from Southern Biotech (Birmingham, AL, USA). Fluorenylmethyloxycarbonyl protected valine was a gift from K. Fath. The peptide sequences KLGFFAH and EDPHNEVDGDK were custom ordered from GenScript (Piscataway, NJ, USA). Buffer solutions, sodium hydroxide pellets were purchased from Fisher Scientific (Waltham, MA, USA).

\subsection{Methods}

\subsubsection{Preparation of Fmoc-Valyl-Cetylamide (FVC) Fibrous Assemblies}

Fmoc-Valyl-Cetylamide (FVC) was prepared according to previously established methods [38]. To prepare the fibrous assemblies, the product $(1 \mathrm{mM})$ was allowed to self-assemble at $\mathrm{pH} 7$ for a period of 3-4 weeks. The formed assemblies were sonicated for $30 \mathrm{~min}$ to dissociate any aggregates and were then washed and centrifuged thrice in distilled water and stored at $4{ }^{\circ} \mathrm{C}$. 


\subsubsection{Layer-by-Layer Assembly of Construct I (FVC-DSp-Col-I-Ch-CS)}

To $1 \mathrm{~mL}$ of self-assembled FVC fibrous assemblies, DSp sequence (200 $\mu \mathrm{L}, 1 \mathrm{mg} / \mathrm{mL})$ (EDPHNEVDGDK) was added and shaken for two hours at $4{ }^{\circ} \mathrm{C}$. The mixture was then allowed to sit undisturbed for one hour followed by centrifugation and washed with distilled water twice to remove unbound DSp. The FVC-bound DSp was then incubated with Type I collagen (Col-I) $(200 \mu \mathrm{L}, 1 \mathrm{mg} / \mathrm{mL})$ and shaken for two hours at $4{ }^{\circ} \mathrm{C}$, and allowed to sit undisturbed for three hours. The samples were then centrifuged and washed with distilled water twice to remove unbound Col-I. To the FVC-DSp-Col-I assemblies, chitosan $(200 \mu \mathrm{L}$ in acetic acid, $1 \mathrm{mg} / \mathrm{mL})$ was added and allowed to incubate at $4{ }^{\circ} \mathrm{C}$ for two hours followed by centrifugation and washed to remove unbound chitosan. Finally, chondroitin sulfate $\left(200 \mu \mathrm{L}, 1 \mathrm{mg} / \mathrm{mL}\right.$ ) was added and allowed to incubate at $4{ }^{\circ} \mathrm{C}$ for $48 \mathrm{~h}$. Construct I (FVC-DSp-Col-ICh-CS) was then centrifuged and washed twice with distilled water before further analysis.

\subsubsection{Layer-by-Layer Assembly of Construct II (FVC-CP-Col-II-Ch-CS)}

To $1 \mathrm{~mL}$ of FVC fibrous assemblies, CP sequence (KLGFFAH) $(200 \mu \mathrm{L}, 1 \mathrm{mg} / \mathrm{mL})$ was added and shaken for two hours at $4{ }^{\circ} \mathrm{C}$ and then allowed to sit undisturbed for one hour followed by centrifugation for $30 \mathrm{~min}$ and washed with distilled water twice to remove unbound $\mathrm{CP}$. The FVC-bound $\mathrm{CP}$ was then incubated with Type II collagen (Col-II) $(200 \mu \mathrm{L}, 1 \mathrm{mg} / \mathrm{mL})$ and shaken for one hour at $4{ }^{\circ} \mathrm{C}$, and then allowed to sit undisturbed for three hours. The samples were then centrifuged and washed with distilled water twice to remove unbound Col-II. To the FVC-CP-Col-II assemblies, chitosan solution $(200 \mu \mathrm{L}$ in acetic acid, $1 \mathrm{mg} / \mathrm{mL}$ ) was added and allowed to incubate at $4{ }^{\circ} \mathrm{C}$ for two hours followed by centrifugation and washing to remove unbound chitosan. As the last layer, chondroitin sulfate $(200 \mu \mathrm{L}$, $1 \mathrm{mg} / \mathrm{mL}$ ) was added and allowed to incubate at $4{ }^{\circ} \mathrm{C}$ for $48 \mathrm{~h}$. Construct II (FVC-CP-Col-II-Ch-CS) was then centrifuged and washed twice with distilled water before further analysis.

\subsection{Characterization}

\subsubsection{Scanning Electron Microscopy (SEM)}

The morphologies of the scaffold constructs were probed using a Zeiss Evo MA10 scanning electron microscope operated at a range of $3-10 \mathrm{kV}$. The formed fibrous matrices were air-dried on carbon-coated tape prior to imaging.

\subsubsection{Fourier Transform Infrared Spectroscopy (FTIR)}

FTIR analyses were performed using a Thermo Scientific Nicolet IS50 FTIR with OMNIC software. To confirm the incorporation of each layer, FTIR spectroscopy was conducted by preparing KBr pellets of each dried sample. Spectra were taken at $4 \mathrm{~cm}^{-1}$ resolution with 100 scans for averaging. Measurements were carried out between 400 and $4000 \mathrm{~cm}^{-1}$. 


\subsubsection{Differential Scanning Calorimetry}

Differential scanning calorimetry studies were conducted using a TA Instruments Q200 DSC. Each construct ( $1 \mathrm{mg}$ ) was allowed to dry and was weighed and placed in an aluminum pan and sealed. The phase transitions were examined by ramping up from $5.00{ }^{\circ} \mathrm{C}$ to $300{ }^{\circ} \mathrm{C}$ by increments of $5.00{ }^{\circ} \mathrm{C}$.

\subsubsection{Mechanical Testing of Constructs}

The mechanical properties of the hybrid scaffold constructs I and II were tested using a XEI-Park Systems AFM by using nanoindentation method carried out using PPP-NCHR-20 S/N cantilever. For analysis, the samples were first dried on to glass slides and then imaged in the tapping mode. Force Spectroscopy experiments were then carried out in order to determine the nanomechanical properties of the samples. The cantilever and tip were allowed to approach and contact the samples and then retracted and the interactions between the tip and the sample were measured at various locations in the samples. Force-vs.-displacement curves were then fitted into Hertzian model and the Young's Moduli were calculated by XEI data processing and analysis software $[63,64]$. Studies were carried out at various regions on the scaffold constructs and the data reported are an average of $n=4$.

\subsection{Cell Studies}

\subsubsection{Cell Imaging}

Bovine chondrocyte cells acquired from Astarate Biologics were cultured at $37{ }^{\circ} \mathrm{C}$ under humidified atmosphere of 5\% $\mathrm{CO}_{2}$ DMEM (1X) + GlutaMAX ${ }^{\mathrm{TM}}$ Dulbecco's Modified Eagle Medium (ATCC) supplemented with $4.5 \mathrm{~g} / \mathrm{L}$ D-Glucose, $10 \%$ fetal calf serum, and $3 \%$ of Penicillin-Streptomycin $(5000 \mathrm{IU} / \mathrm{mL}$ Penicillin, $5 \mathrm{mg} / \mathrm{mL}$ Streptomycin). Cells were grown for $96 \mathrm{~h}$ to confluency. Cells were plated at $4 \times 10^{4}$ of cells/well in a 24-well tissue culture plate and incubated with varying amounts of both constructs. In general, $8 \mu \mathrm{M}$ and $30 \mu \mathrm{M}$ of constructs were added to separate wells. The morphologies of the cells and their interactions with the constructs were then examined every $24 \mathrm{~h}$. Images were acquired using an inverted trinocular phase contrast microscope. For SEM imaging, cells were incubated with $30 \mu \mathrm{M}$ of each of the scaffold constructs and placed in 6 well plates containing treated coverslips for a period of $48 \mathrm{~h}$, following which they were rinsed with PBS. The washed cells were fixed with $2 \%$ formaldehyde for an hour, followed by addition of buffer (30 mM HEPES, $100 \mathrm{mM} \mathrm{NaCl}, 2 \mathrm{mM} \mathrm{CaCl} 2$ ). They were then treated with $1 \% \mathrm{OsO}_{4}$ for $1 \mathrm{~h}$ at room temperature. The cells were then rinsed with distilled water and dehydrated through consecutive steps of treatment with $30 \%, 50 \%, 75 \%$, and $90 \%$ ethanol at room temperature and finally $100 \%$ ethanol. The cover slips were then washed with hexamethyldisilazane (HMDS) which was allowed to evaporate at room temperature. The coverslips were carbon coated before being analyzed by SEM.

\subsubsection{Cell Proliferation}

To study cell proliferation and growth, MTT assay was conducted by incubating cells at $2 \times 10^{4}$ cells/well in a 96-well tissue culture plate with varying amounts of Construct I and II ( $8 \mu \mathrm{M}$ and $20 \mu \mathrm{M})$ as well as control cells (without constructs) and media alone (no cells or constructs). Analysis was performed at 
three time points of 24-h, 48-h, and 72-h periods. In general, $10 \mu \mathrm{L}$ of MTT reagent was pipetted into each of the wells and agitated gently for 2 min to ensure proper mixing. After this addition, the well plates were returned back into the incubator for $3 \mathrm{~h}$, until a purple colored solution was observed, which was then aspirated off and was immediately followed by addition of $100 \mu \mathrm{L}$ of crystal dissolving solution to each well to dissolve formazan crystals that had formed. The solution was then agitated gently to ensure thorough mixing and placed in a BioTek Eon Microplate spectrometer for data analysis. The absorbance at $570 \mathrm{~nm}$ was recorded for each well to determine cell viability and subtracted from the blank. All readings were taken in triplicate and the mean values and standard deviations were calculated.

\subsubsection{Chondrogenesis Assay}

To examine the formation of proteoglycans, an inherent process in chondrogenesis, Alcian blue assay was performed. The assay kit was purchased from Biomedical Research Service and Clinical Application (Buffalo, NY, USA). For the assay, cells were cultured in 24 well plates in media in the presence of constructs as per methods mentioned above. Cells were grown in media containing DMEM high glucose, fetal calf serum $(10 \%)$, nonessential amino acids, penicillin/streptomycin $(100 \mathrm{U} / 100 \mathrm{mg} / \mathrm{mL}), 1 \%$ sodium pyruvate and proline. Transforming growth factor (TGF- $\beta 1)(10 \mathrm{ng} / \mathrm{mL})$ was also added to the culture plates containing $3 \times 10^{4}$ cells/ well and incubated with $100 \mu \mathrm{L}$ of Construct I or Construct II as well as controls without constructs. Tests for proteoglycan staining were carried out after incubation for 7 days, 14 days, and 21 days. Briefly for each test, the culture medium was aspirated off and the cells were washed with PBS buffer. The PBS buffer was then removed. To each of the wells, $0.5 \mathrm{~mL}$ of $4 \%$ paraformaldehyde was then added. The cells were fixed for five minutes at room temperature. Paraformaldehyde was then aspirated off and the fixed cells were rinsed twice with distilled water, followed by complete removal of water. To each of the wells, $0.5 \mathrm{~mL}$ of $1 \%$ Alcian blue solution was then added and the well plates were gently agitated at room temperature for $30 \mathrm{~min}$. The Alcian blue solution was then aspirated off and the stained cells were washed with distilled water twice for less than a minute, followed by the removal of water. Stained cells were then imaged under an optical microscope. For quantitative analysis, $0.5 \mathrm{~mL}$ of $1 \mathrm{~N} \mathrm{HCl}$ was added to each well to extract cell-bound Alcian blue and agitated for $30 \mathrm{~min}$ to ascertain complete dye extraction. The $\mathrm{HCl}$ solution was then harvested and the O.D. was measured at $620 \mathrm{~nm}$ using a Nanodrop $2000 \mathrm{UV}-\mathrm{V}$ is spectrophotometer. The amount of Alcian blue bound to cells is directly proportional to O.D. The concentrations were calculated by comparing results obtained with that obtained from standard curve. For the standard curve, various concentrations of chondroitin sulfate had been used.

\subsubsection{Soluble Collagen Assay}

Since chondrocyte differentiation is associated with increased collagen synthesis, the quantities of soluble collagen synthesized and exuded into the culture medium by the chondrocytes in the presence of constructs I and II were determined over a period of $120 \mathrm{~h}$ by conducting Sircol Assay by modification of previously established methods [65]. The total amount of soluble collagen secreted by different amounts of constructs was determined by multiplying the collagen concentration, (which was obtained from the calibration curve), with the volume of the culture media, and results reported are the ratio of the collagen produced in the presence of the constructs to that of control cells. Each study was carried out thrice. 


\subsection{Statistical Analysis}

Data shown are representative of repeated experiments. Triplicate samples were used for cell assays and for microscopy analysis. Numerical data is expressed as mean \pm standard error of the mean. Analysis was performed using ANOVA software with confidence level of $90 \%$. Statistical significance was set at $p<0.05$.

\section{Results}

\subsection{Formation of Scaffold Constructs}

Two separate fibrous scaffolds were prepared for potential applications in cartilage tissue regeneration. Both scaffolds were formed by utilizing Fmoc-valyl cetyl amide (FVC) fibers as templates which were then bound to ECM-mimicking components. We wished to compare how the effects of varying the composition of the scaffolds would affect their ability to adhere to and allow for proliferation of chondrocytes. The SEM image of the template FVC is shown in Figure 1a. The FVC template is characterized by distinct fibers $200-500 \mathrm{~nm}$ in diameter. These nanofibers show pronounced aggregation and appear to stack on top of one another to develop matrix-like structures. The fibrous nature of FVC is likely a result of the long hexadecyl carbon chain which allows for self-assembly because of strong hydrophobic interactions. Furthermore, the aromatic groups present from the Fmoc moiety provide $\pi-\pi$ stacking interactions which also contribute to the assembly of the fibers. Subsequent addition of each layer for preparation of Construct $\mathrm{I}$ is indicated in Figure 1b-e. Upon addition of the DSp derived sequence (EDPHNEVDGDK), distinct fibrils were observed on the surface of the FVC fibers (Figure 1b) that ranged from 20 to $50 \mathrm{~nm}$ in diameter and were evenly dispersed throughout the matrix. Type I collagen was the next layer incorporated as shown in Figure 1c. The incorporation of Col-I was confirmed by the mesh of fibrillar aggregates $2-5 \mu \mathrm{m}$ in diameter which were found to readily attach to the DSp-bound FVC assemblies. For the next layer, Ch was added to the FVC-DSp-Col-I composite as shown in Figure 1d. Upon attachment of $\mathrm{Ch}$, the matrices appeared to be coated with a layer of Ch-derived film which uniformly covered the matrix. Pronounced crests and troughs regularly distributed were observed, indicating the facile assimilation of the film. CS provided the final layer for Construct I (Figure 1e). The surface is characterized by a distinct rough topography with pronounced network-like structures ranging from 5 to $10 \mu \mathrm{m}$ in diameter.

Construct II (Figure 2a-d) was also prepared by layer-by-layer assembly via non-covalent binding interactions between each consecutive layer to develop scaffolds. There was a noticeable difference, however, upon incorporation of the Col-II binding peptide sequence CP (KLGFFAH) to the FVC assemblies (Figure 2a) as compared to the DSp segment (Figure 1b). A proteinaceous coating of self-assembled thin fibers ranging in diameters from 50 to $100 \mathrm{~nm}$ coating the FVC templates was observed. This indicated that the $\mathrm{CP}$ peptide most likely self-assembled in the presence of the FVC assemblies and wrapped around them. Integration of Col-II to FVC-CP composites is shown in Figure 2b. Col-II assemblies completely covered the FVC-CP composites and large fibrous matrices 5-10 $\mu \mathrm{m}$ in diameter were observed. The topography of the FVC-CP-Col-II is attributed to the triple-helical fibrous nature of collagen [66]. Upon incorporation of $\mathrm{Ch}$, a gelatinous matrix was observed (Figure 2c) which is again distinctly different from the matrix observed upon incorporation of $\mathrm{Ch}$ for Construct I. This difference 
in morphology is likely due to differences in interactions between FVC-CPs-Col-II composites. The final layer, in which CS was added, showed the formation of a fibrous mesh which completely coated the FVC-CPs-Col-II-Ch bound composites (Figure 2d). These results confirm that two distinct constructs were prepared by altering the peptide composition of the matrices.

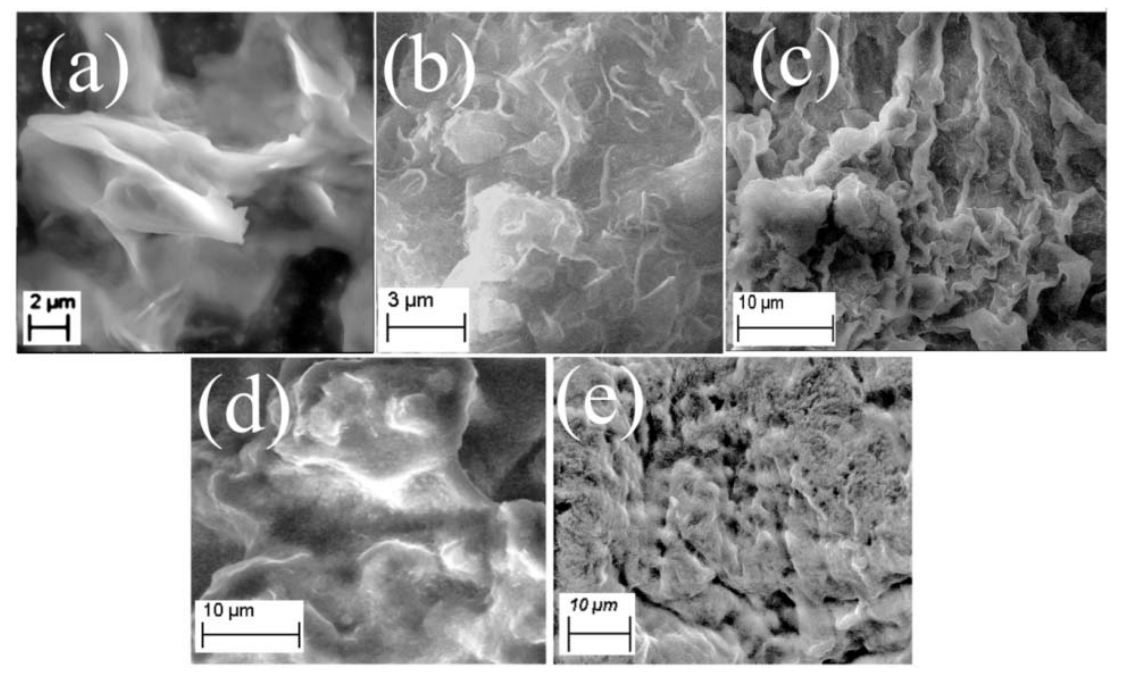

Figure 1. Scanning electron microscopy images depicting layer-by-layer assembly of Construct I. (a) FVC fibrous assemblies; (b) FVC fibers layered with DSp peptide sequence; (c) Incorporation of Type I collagen (Col-I) to FVC-DSp; (d) Incorporation of chitosan (Ch) to FVC-DSp-Col-I; (e) Final Construct I scaffolds after attachment of chondroitin sulfate to FVC-DSp-Col-I-Ch.
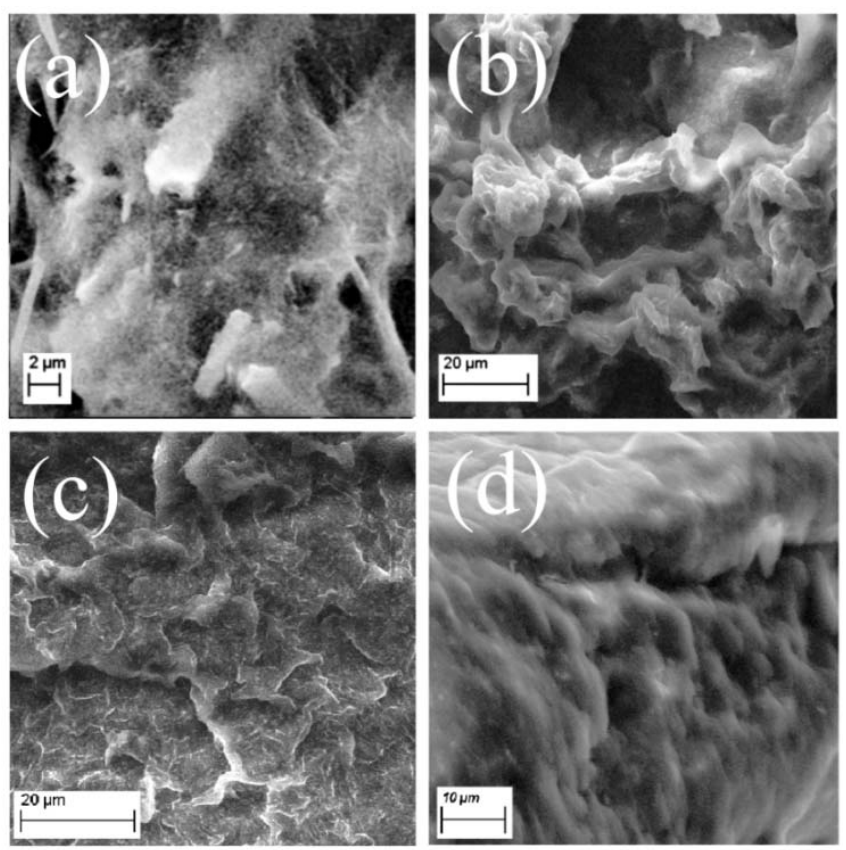

Figure 2. Scanning electron micrographs depicting layer-by-layer assembly of Construct II. (a) FVC fibrous assemblies layered with CP peptide; (b) Incorporation of Type II collagen (Col-II) to FVC-CP assembly; (c) Incorporation of Ch to FVC-CP-Col-II; (d) Final Construct II scaffolds after attachment of CS to FVC-CP-Col-II-Ch. 


\subsection{FTIR Spectroscopy}

To probe the incorporation of each layer to both Construct I and Construct II, Fourier transform infrared spectroscopy (FTIR) was conducted (Figure 3).

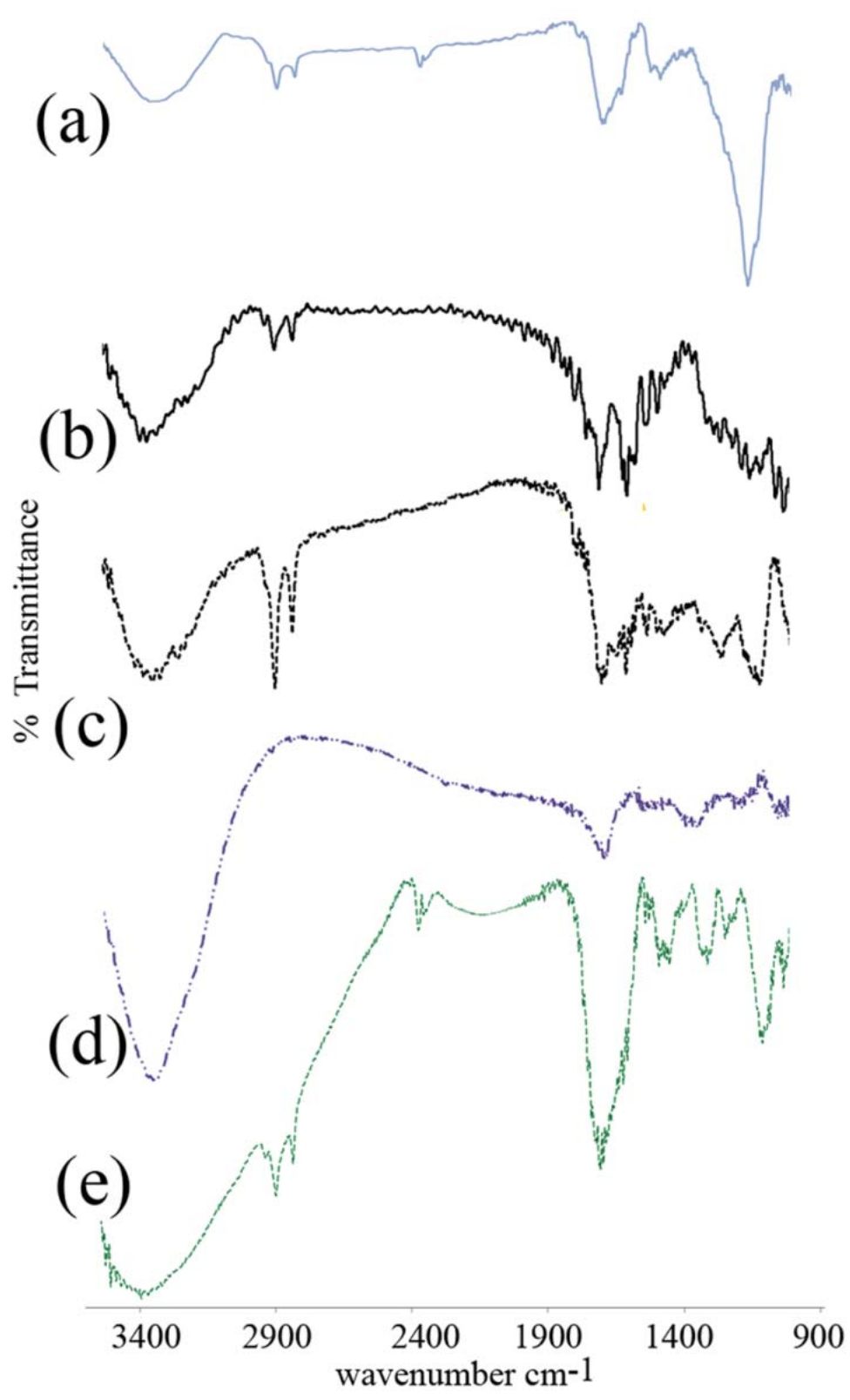

Figure 3. Comparison of Fourier Transform Infrared Spectroscopy (FTIR) spectra of each incorporated layer in Construct I. (a) FVC primary layer; (b) FVC-DSp; (c) FVC-DSp-Col-I; (d) FVC-DSp-Col-I-Ch; (e) FVC-DSp-Col-I-Ch-CS.

Spectra of Construct $\mathrm{I}$ are shown in Figure $3 \mathrm{a}-\mathrm{d}$. The peaks due to amide $\mathrm{I}$ and amide II $\mathrm{C}=\mathrm{O}$ functionality (1500-1700 $\mathrm{cm}^{-1}$ region) arise primarily from stretching vibrations of the carbonyl groups and their sensitivity to secondary structural transformations provides direct structural information [67,68]. For FVC fibers, we observed an amide I peak at $1660 \mathrm{~cm}^{-1}$ and a short shoulder was observed at 1585 $\mathrm{cm}^{-1}$ due to the amide II peak as well as a short amide III peak seen at $1480 \mathrm{~cm}^{-1}$. A sharp peak was observed at $1120 \mathrm{~cm}^{-1}$ due to bending vibrations of the long chain $\mathrm{C}-\mathrm{H}$ aliphatic cetyl group as well as 
the presence of the aromatic Fmoc group [69]. Additionally, peaks were observed at $2930 \mathrm{~cm}^{-1}$ due to $\mathrm{C}-\mathrm{H}$ stretching vibrations [70]. A short broad peak was observed at $3500 \mathrm{~cm}^{-1}$ possibly due to secondary amide H-bonding interactions. Upon addition of the DSp sequence, we observed distinct changes particularly in the carbonyl region. Amide I peaks were observed at $1646 \mathrm{~cm}^{-1}$ with a shoulder at $1636 \mathrm{~cm}^{-1}$. The amide II peak was observed at $1542 \mathrm{~cm}^{-1}$ and the amide III peak was shifted to $1508 \mathrm{~cm}^{-1}$. Additionally, the peak at $3500 \mathrm{~cm}^{-1}$ was significantly broader compared to FVC assemblies due to presence of carboxyl groups in glutamic and aspartic acid residues present in the DSp segment [71]. Upon incorporation of Col-I, bands at $1495 \mathrm{~cm}^{-1}, 1240 \mathrm{~cm}^{-1}$ and $1190 \mathrm{~cm}^{-1}$ were observed, indicative of the $-\mathrm{CH}_{2},-\mathrm{CH}_{3}, \mathrm{C}-\mathrm{N}$ and $-\mathrm{N}-\mathrm{H}$ stretching [72]. Amide I bands were shifted to $1656 \mathrm{~cm}^{-1}$ and $1638 \mathrm{~cm}^{-1}$, whereas the amide II peak was shifted to $1544 \mathrm{~cm}^{-1}$ with a short shoulder at $1525 \mathrm{~cm}^{-1}$. The $-\mathrm{OH}$ peak is primarily due to hydroxy-proline groups present in collagen resulting in the inter- and intra-chain hydrogen bonding interactions with the previous layer as well as within collagen molecules themselves. Subsequent addition of Ch demonstrated an enhancement in the peak between 3200 and $3600 \mathrm{~cm}^{-1}$ which was significantly broad compared to previous layers [73]. This is primarily due to hydroxyl and amine groups present in the glucosamine moiety of chitosan [74,75]. Additionally, shifts were observed in the carbonyl amide I region to $1643 \mathrm{~cm}^{-1}$ and the amide II peak was found to shift to $1503 \mathrm{~cm}^{-1}$, with additional peaks observed $1485 \mathrm{~cm}^{-1}, 1350 \mathrm{~cm}^{-1}$ and $1275 \mathrm{~cm}^{-1}$, respectively [76]. Incorporation of the final layer of CS yielded results in shifts in the carbonyl region with strong amide I peaks at $1634 \mathrm{~cm}^{-1}$ and at $1649 \mathrm{~cm}^{-1}$ while amide II peaks were observed at $1556 \mathrm{~cm}^{-1}$ and at $1539 \mathrm{~cm}^{-1}$. The peak in the $-\mathrm{OH}$ region was significantly broader and more intense signifying the incorporation of CS [77].

FTIR spectra of Construct II are shown in Figure $4 \mathrm{a}-\mathrm{d}$. The peaks obtained for FVC templates have already been explained above (Figure 3a). The first layer attached was the CP short sequence (KLGFFAH). The FVC-CP spectra demonstrated a broad peak in the amide I region with split peaks at $1637 \mathrm{~cm}^{-1}$ and $1647 \mathrm{~cm}^{-1}$ as well as an amide II peak at $1575 \mathrm{~cm}^{-1}$ and amide III peaks at $1457 \mathrm{~cm}^{-1}$ and $1419 \mathrm{~cm}^{-1}$, respectively. Upon incorporation of Col-II, we observed distinct changes in this region. Multiple peaks were observed in the carbonyl region at $1743 \mathrm{~cm}^{-1}$ and at $1712 \mathrm{~cm}^{-1}, 1650 \mathrm{~cm}^{-1}, 1544 \mathrm{~cm}^{-1}, 1521 \mathrm{~cm}^{-1}$, $1528 \mathrm{~cm}^{-1}$ and $1496 \mathrm{~cm}^{-1}$. Furthermore, amide III peaks demonstrated characteristic shifts to $1496 \mathrm{~cm}^{-1}$ and $1399 \mathrm{~cm}^{-1}$. Such split peaks are characteristic of Col-II and thus confirms the incorporation of Col-II to FVC-CP composites [78]. Upon incorporation of $\mathrm{Ch}$, once again a broadening of the hydroxyl region peak was observed as expected. The peaks in the amide I region were found at $1622 \mathrm{~cm}^{-1}$ and at $1642 \mathrm{~cm}^{-1}$ while amide II peaks appeared at $1565 \mathrm{~cm}^{-1}$ and $1548 \mathrm{~cm}^{-1}$. Amide III peaks were shifted to $1470 \mathrm{~cm}^{-1}$ and $1420 \mathrm{~cm}^{-1}$. Upon final addition of CS, the amide I peak was observed shifted to $1610 \mathrm{~cm}^{-1}$ with amide II peaks also slightly red shifted to $1568 \mathrm{~cm}^{-1}$ and $1547 \mathrm{~cm}^{-1}$. Amide III peaks also demonstrated red shifts at $1410 \mathrm{~cm}^{-1}$ and $1390 \mathrm{~cm}^{-1}$. These shifts in the spectra upon incorporation of each layer confirm the formation of the composite assemblies. 


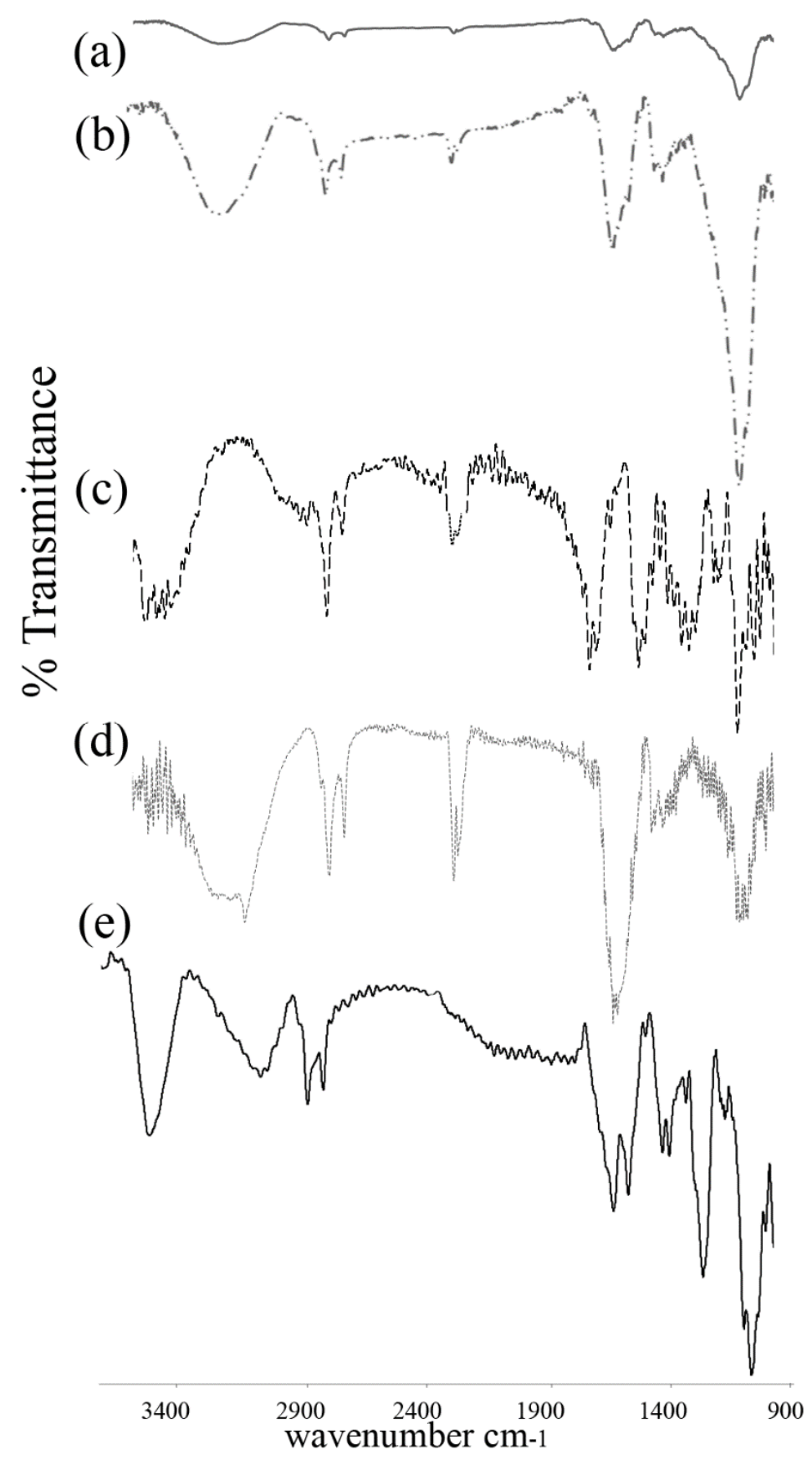

Figure 4. Comparison of FTIR spectra of each incorporated layer in Construct II. (a) FVC primary layer; (b) FVC-CP; (c) FVC-CP-Col-II; (d) FVC-CP-Col-II-Ch; (e) FVC-CP-Col-II-Ch-CS.

\subsection{Differential Scanning Calorimetry}

To examine the thermal properties of Construct I and Construct II as a function of temperature, differential scanning calorimetry (DSC) analysis was conducted (Figure 5). The DSC thermogram for Construct I showed a strong exothermic peak at $8.8^{\circ} \mathrm{C}$ as well as a small exothermic shoulder at $21.9{ }^{\circ} \mathrm{C}$. Additionally, broad endothermic peaks were observed at $54{ }^{\circ} \mathrm{C}$ and at $79{ }^{\circ} \mathrm{C}$ followed by a very broad endothermic peak between 105 and $220^{\circ} \mathrm{C}$. Construct II was characterized by a sharp exothermic peak at $16.8{ }^{\circ} \mathrm{C}$ in addition to two short exothermic peaks at $25{ }^{\circ} \mathrm{C}$ and $30{ }^{\circ} \mathrm{C}$, respectively. A broad 
endothermic peak was observed in the region between 40 and $102{ }^{\circ} \mathrm{C}$ followed by another broad peak in the region between 107 and $210{ }^{\circ} \mathrm{C}$ similar to that observed in the case of Construct I.

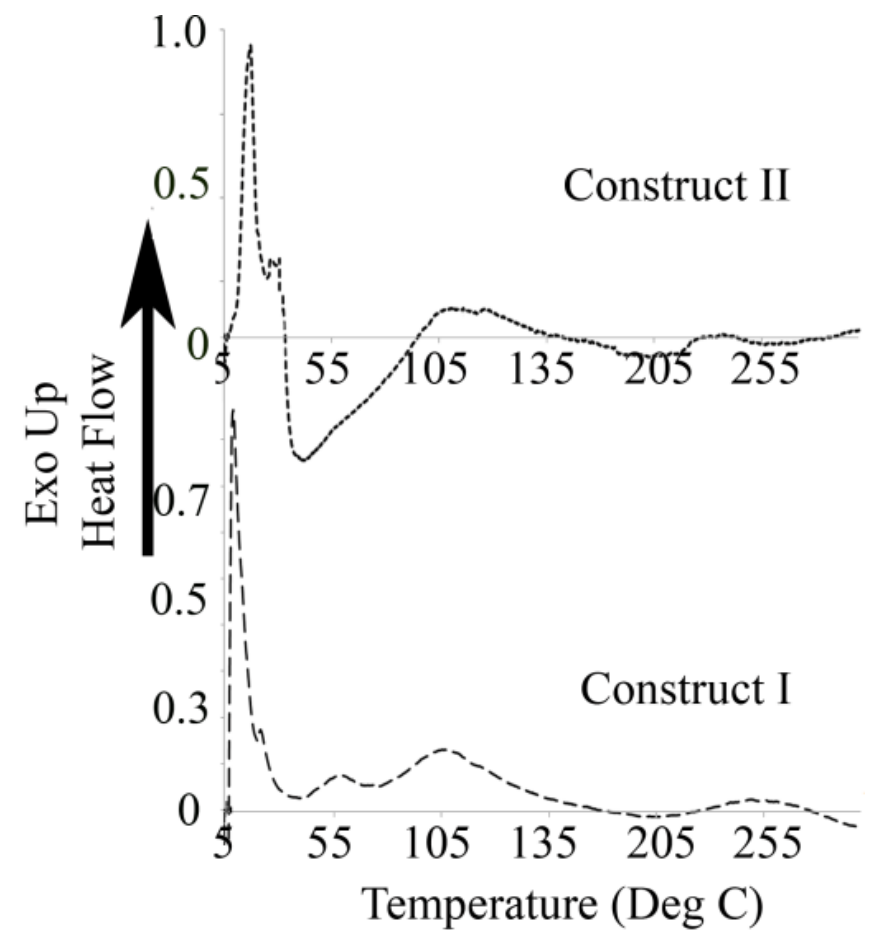

Figure 5. Comparison of DSC thermograms of Construct I and Construct II.

\subsection{AFM imaging and Nanomechanical Properties}

In order to determine the nanomechanical properties of the scaffold constructs, AFM was carried out for Construct I and Construct II. The results obtained are shown in Figure 6. The AFM amplitude image of Construct I is shown in Figure 6a, while Figure 6b shows the corresponding line profile graph showing the roughness of the scaffold. For Construct I, the average surface roughness Ra value was found to be $0.83 \mathrm{~nm}$, while the ten point surface roughness taking into account the average of highest five peaks and valleys $(\mathrm{Rz})$ was found to be $4.26 \mathrm{~nm}$. Figure 6c,d show the AFM height image obtained for Construct II and the corresponding line profile graph. The average surface roughness Ra was found to be $0.24 \mu \mathrm{m}$ and the $\mathrm{Rz}$ value was found to be $0.85 \mu \mathrm{m}$. Figure 6e,f show the force vs. displacement curves obtained by nanoindentation at various local points within the matrices. To determine the Young's Moduli, results were fit into Hertzian model. The Young's Modulus was found to be $208.1 \mathrm{kPa}$ for Construct I and $551.3 \mathrm{kPa}$ for Construct II. 

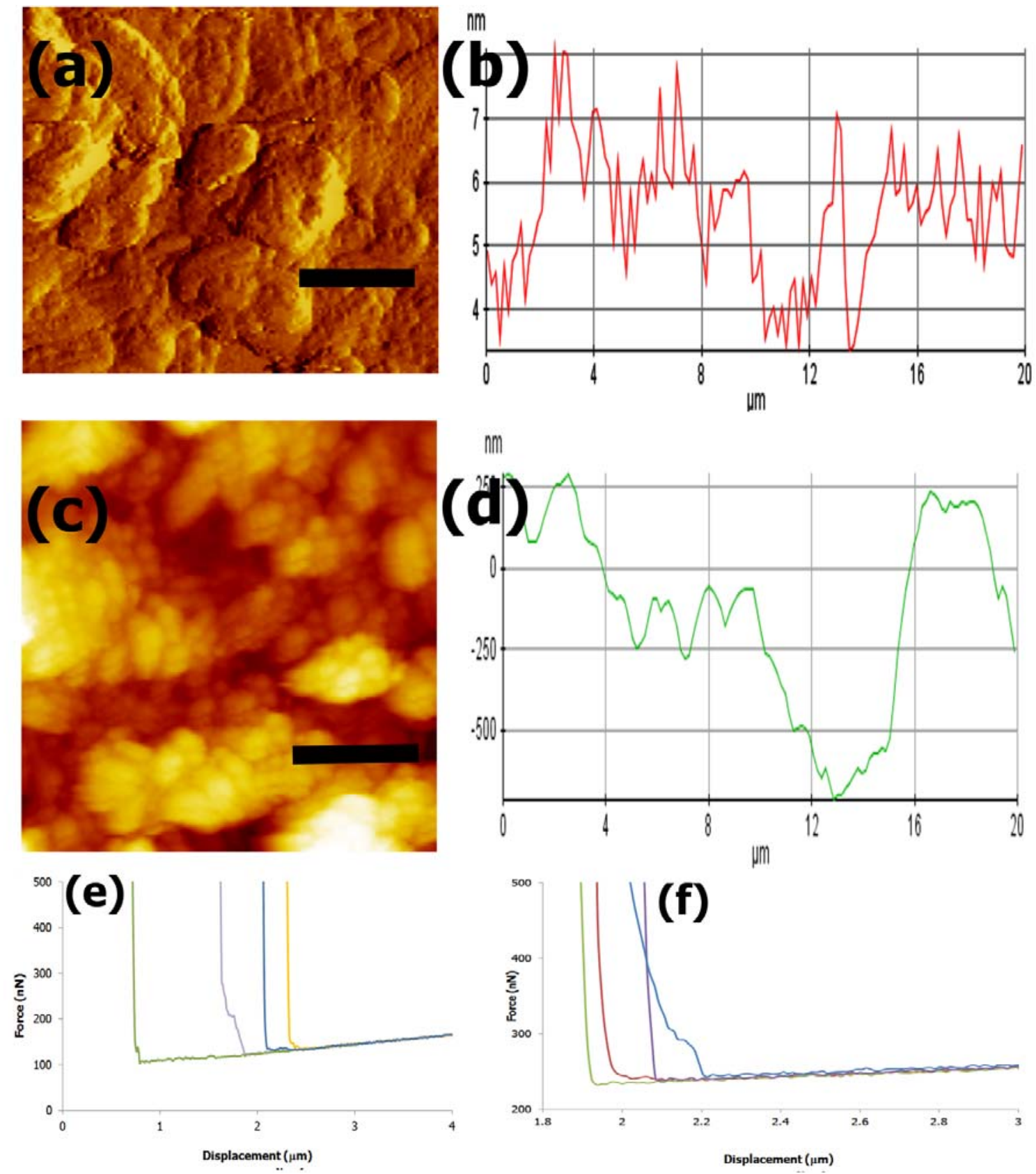

Figure 6. (a) Construct I AFM amplitude image, scale bar $=5 \mu \mathrm{m}$ and (b) Line profile graph indicating surface roughness for Construct I; (c) Construct II AFM height image, scale bar $=4 \mu \mathrm{m}$ and (d) Line profile graph showing roughness of Construct II; (e) Force vs. Z displacement curves for Construct I and (f) Force vs. Z displacement curve for Construct II at various local regions of contact.

\subsection{Cell Studies}

\subsubsection{Cell Morphology and Attachment to Constructs}

To examine the interactions of the constructs with chondrocytes, we conducted optical microscopy studies. Cells were incubated with constructs for a period of 24 to $144 \mathrm{~h}$ to examine the effects of the constructs on the cells. Results obtained were compared with the morphology of control cells (Figure 7). Figure 7a shows the optical microscopy image obtained for control cells after $24 \mathrm{~h}$ of growth, while 
Figure 7b,c show corresponding images of cells grown in the presence of Constructs I and II after a period of $96 \mathrm{~h}$ and $72 \mathrm{~h}$ respectively. Results indicate that the cells were able to adhere to the constructs and proliferate over time. The images shown are those obtained in the presence of $10 \mu \mathrm{M}$ constructs. For Construct II, it was observed that more cells were efficiently incorporated throughout the matrix forming cell-scaffold three dimensional matrices in lesser period of time, indicating higher proliferation and attachment for Construct II. In general in both cases, the results show that the cells continued to grow and maintain natural spherical morphology, similar to that of the control [79]. However, faster and more significant attachment and formation of 3D-cell-scaffold matrices was observed in the case of Construct II whereas similar attachment was seen only in patches for Construct I. To further examine the interactions between the cells and the scaffold constructs, we also conducted scanning electron microscopy. Results are shown in Figure 7d,e for Constructs I and II respectively. As seen in the images, both constructs completely attached to the cells, however more extensive scaffolds were formed in the presence of Construct II.
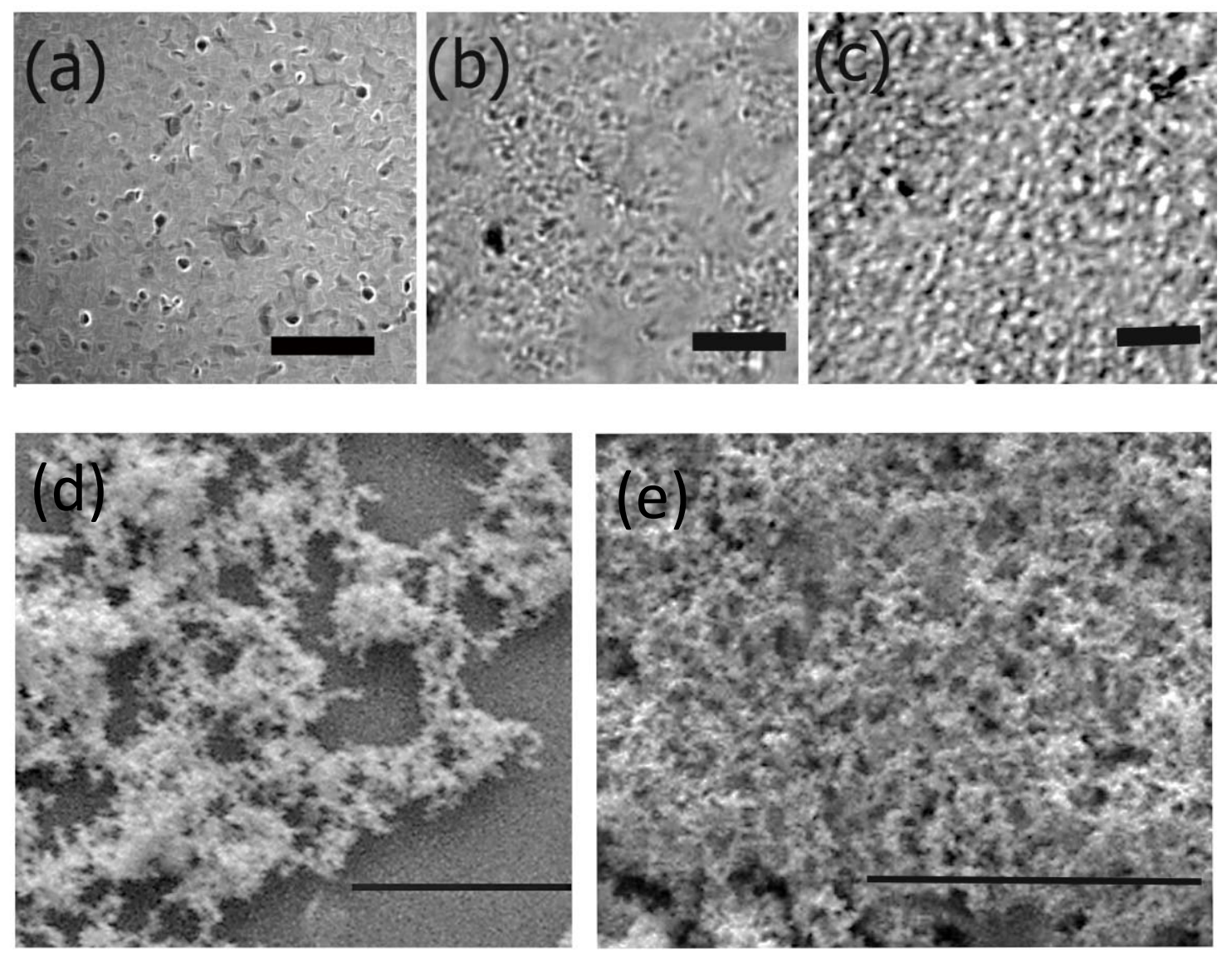

Figure 7. Phase contrast optical microscopy images of cells in the absence and presence of constructs (a) Control cells after $24 \mathrm{~h}$ (scale bar $=50 \mu \mathrm{m}$ ); (b) Cells seeded with Construct I after $96 \mathrm{~h}$ (scale bar $=50 \mu \mathrm{m})$; (c) Cells seeded with Construct II after $48 \mathrm{~h}($ scale bar $=50 \mu \mathrm{m})$; (d) Scanning Electron Microscopy (SEM) image of cells seeded with Construct I (scale bar $=50 \mu \mathrm{m})$; (e) SEM image of cells seeded with Construct II (scale bar $=100 \mu \mathrm{m})$. 


\subsubsection{Cell Proliferation Studies}

To quantify cell viability in the presence of the constructs, we conducted MTT colorimetric assays. As seen Figure 8, both constructs showed that cell proliferation continued to occur over time, while percent viability was found to be relatively higher in the case of Construct I. Calculations were done compared to the controls such that the viability of control cells was assumed to be $100 \%$ in all cases. For Construct I, cells continued to proliferate and after $72 \mathrm{~h}$, the percent of viable cells was found to be $83 \%$ with higher viability in the presence of higher amounts of Construct I. For Construct II, the MTT assay results showed continued proliferation across a $72 \mathrm{~h}$ period. Cell proliferation and viability more than doubled for each concentration at each $24 \mathrm{~h}$ time mark and was found to be $67 \%$ after $72 \mathrm{~h}$ at lower amount of constructs and $56 \%$ at higher amount of constructs. The apparent lower proliferation after $24 \mathrm{~h}$ may be due to less cell spreading at the beginning in the presence of the scaffolds. However, proliferation steadily increased with time indicating that the scaffolds are biocompatible.
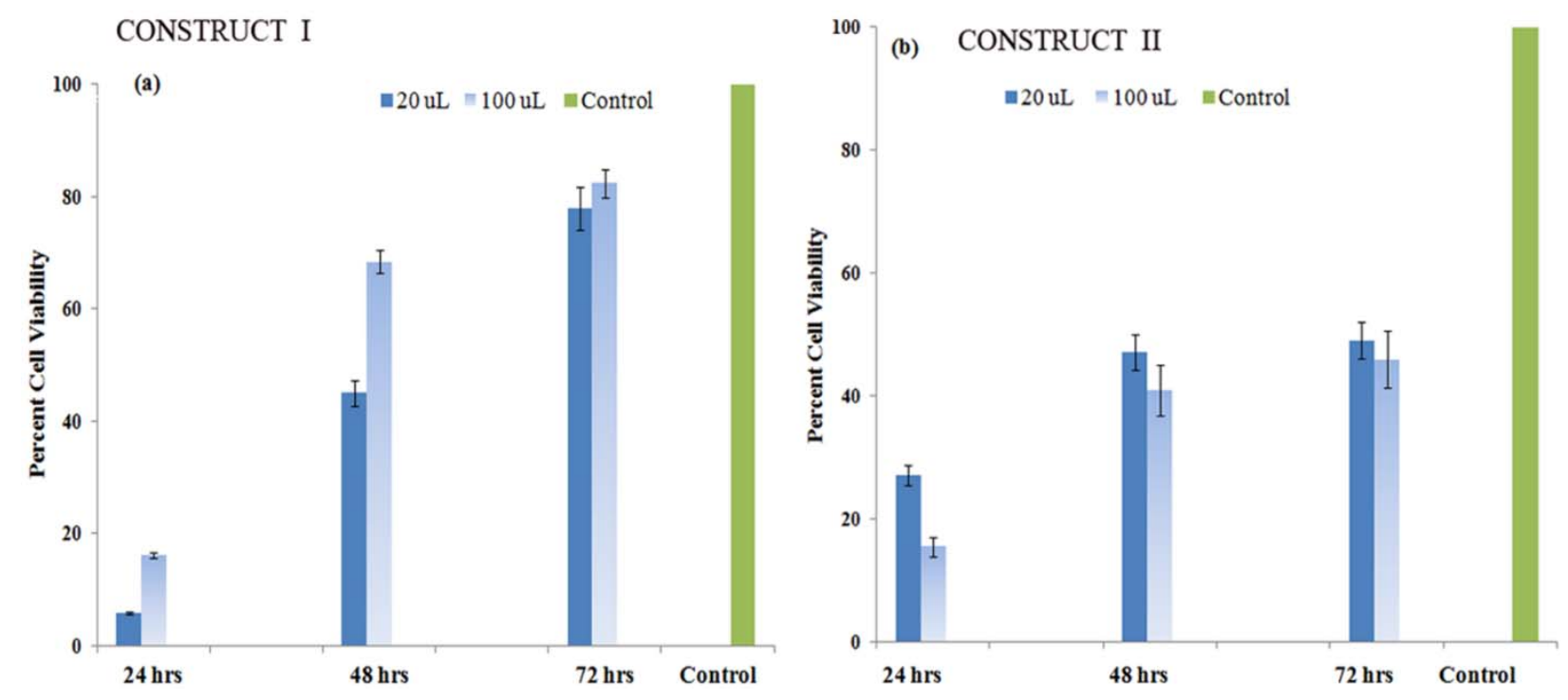

Figure 8. MTT cell viability assay comparing bovine chondrocyte cell proliferation in the presence of (a) Construct I and (b) Construct II.

\subsubsection{Formation of Proteoglycans}

Chondrogenesis is a critical step in cartilage formation and is marked by an increase in extracellular matrix proteoglycan formation during cell differentiation [80]. To examine if the constructs could successfully induce GAG formation in chondrocytes, we conducted Alcian blue assay to indicate the formation of sulfated GAGs. The results obtained are shown in Figure 9. Studies showed that for Construct I initially no significant activity was observed after 4-7 days. In general, higher sulfated GAG production was observed after a two week period. The cell scaffold matrices stained by newly deposited ECM from the chondrocytes indicated proteoglycan synthesis. At day 14, stained proteoglycan formation was higher (Figure 9a) and aggregates of cells were observed. By day 21, enhanced GAG production distributed evenly throughout the matrices was observed along with aggregates of chondrocytes. Sulfated GAG formed in the presence of scaffolds was also quantified by spectrophotometric analysis by examining the increase in absorbance at $620 \mathrm{~nm}$. Our results indicate 
that significantly higher amounts of sulfated GAG production was observed for Construct II compared to Construct I. Overall the \% sulfated GAG formed was found to be $0.62 \%$ for Construct I at the end of 21 days and almost double that (1.13\%) for Construct II as shown in Figure 9b.
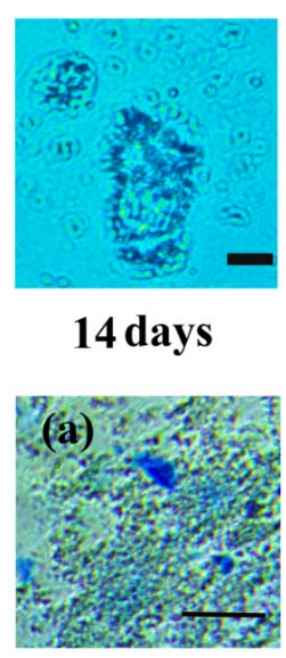

7 days

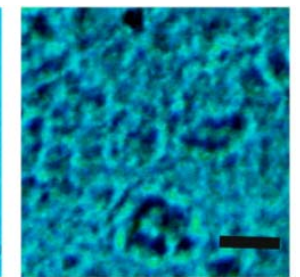

21 days

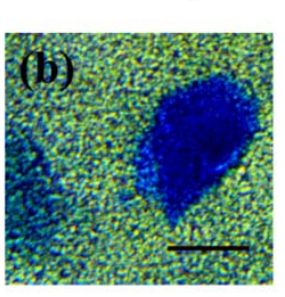

21 days

(a)

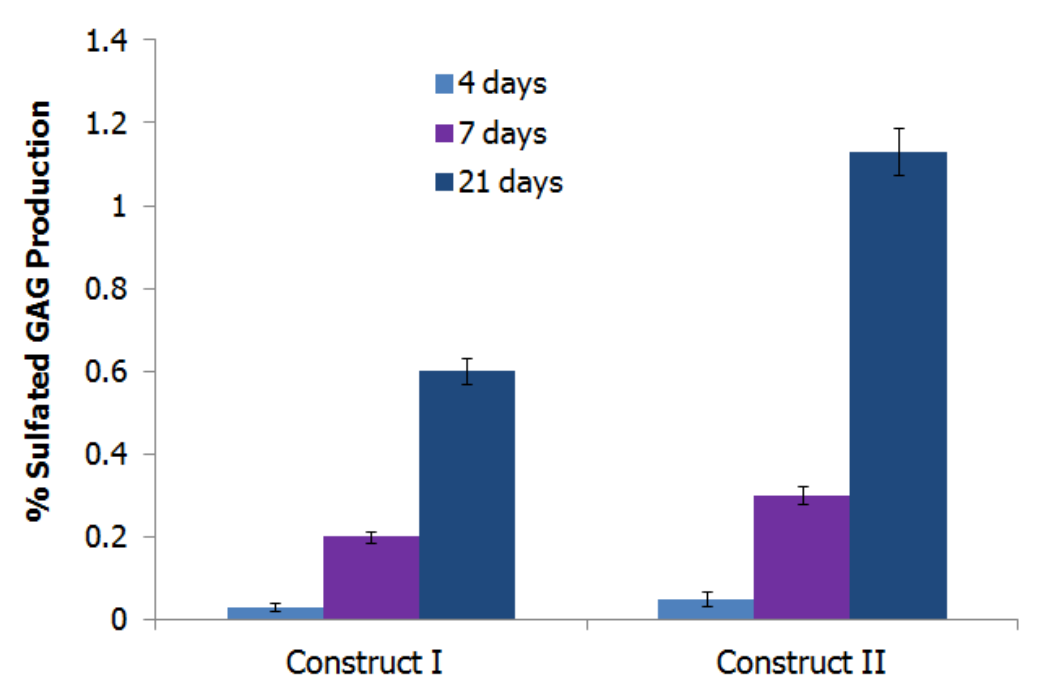

(b)

Figure 9. (a) Alcian blue assay to demonstrate the formation of proteoglycans. Top: Images taken after 14 and 21 days for chondrocytes grown in the presence of Construct I; Bottom: Images taken after 7 and 21 days for chondrocytes grown in the presence of Construct II. Magnification $\times 100$; Scale bars $=50 \mu \mathrm{m}$; (b) Quantification of sulfated glycosaminoglycans (GAG) production.

\subsubsection{Induction of Soluble Collagen}

Collagen is a vital protein that plays an important role in maintaining the structural, mechanical and signaling properties of the extracellular matrices of most tissues including cartilage [81]. Total soluble collagen was quantified after chondrocytes were grown in the culture medium in the presence and absence of the constructs. Our results (Figure 10) indicate that soluble collagen synthesis increased over time. Results were calculated as a ratio of collagen synthesis that occurred in the presence of constructs to that of control cells. Overall, collagen synthesis was found to be relatively higher at lower concentrations of both constructs. After 96 h, collagen synthesis was found to be comparable to that observed for the control cells. At lower concentrations of constructs, soluble collagen synthesis was slightly higher (ratio of 1.06 and 1.04) for Constructs I and II respectively. At higher concentrations, collagen synthesis was slightly lower (ratio of 0.96 for Construct I) while Construct II, showed similar collagen synthesis compared to that of controls at higher concentrations. 


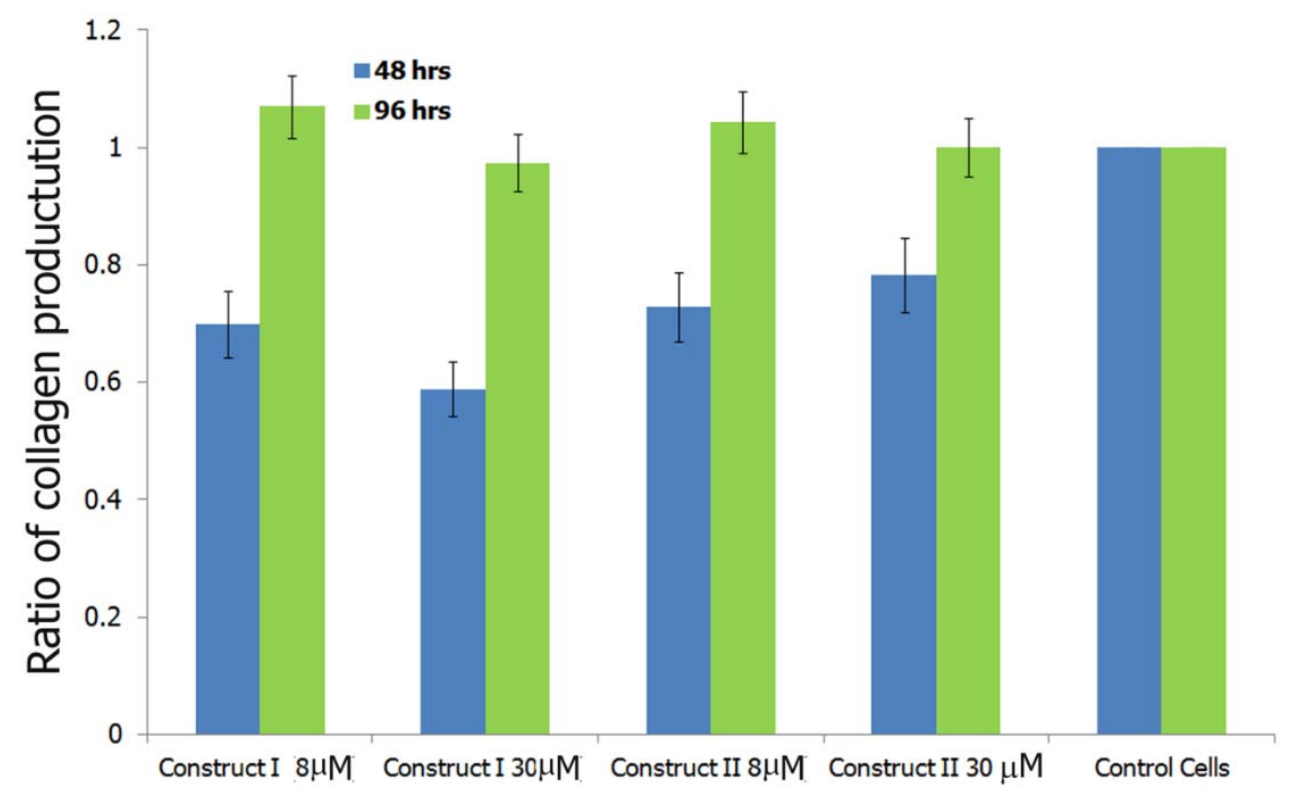

Figure 10. Ratio of soluble collagen synthesis compared to control cells, in the presence of constructs I and II over a period of $48 \mathrm{~h}$ and $96 \mathrm{~h}$.

\section{Discussion}

\subsection{Development of Scaffolds}

Two scaffold constructs were prepared for potential applications in cartilage tissue regeneration. Both Constructs I and II were prepared using FVC fibers as the template primary layer. These fibers were utilized due to their ability to undergo facile self-assembly, their biocompatibility and their ability to efficiently adhere to biomolecules [39,82]. In general, Fmoc based peptides have been shown to inherently support co-assembly with proteins resulting in supramolecular complexes [83]. The presence of a long chain cetyl group not only provides hydrophobicity and supports self-assembly, but also has been shown to promote binding interactions with proteins [84]. Additionally, these fibers may be relatively more stable compared to pure protein based assemblies as the presence of cetyl group has been shown to inhibit trypsin activity which would ordinarily result in rapid proteolysis [85]. Thus, FVC based fibers may form suitable supports for development of scaffolds for cartilage tissue regeneration.

The second layer incorporated to Construct I was the DSp motif EDPHNEVDGDK. The SEM results clearly indicate a change in morphology compared to those observed for the fibers alone and distinct short fibrillar structures with slightly rough surfaces were observed compared to neat FVC fibers. The sequence has a pI value of 3.9 and has net charge of -3 due to the presence of two glutamates and three aspartate groups. However, the presence of histidine and terminal lysine allows for zwitterionic properties. The close proximity of the zwitterionic motif may thus allow for incorporation of the peptide and promote the formation of supramolecular structures thereby modifying the structural morphology of FVC assemblies [86]. Additionally, it also contains aromatic groups such as phenylalanine and histidine while valine as well as asparagine groups make it fairly hydrophobic, promoting $\pi-\pi$ stacking interactions as well as hydrophobic interactions between FVC and the peptide [87]. In addition, H-bonding interactions between the $\mathrm{C}=\mathrm{O}$ and $-\mathrm{NH}$ groups of the peptide and the $\mathrm{FVC}$ amide groups also promote intermolecular interactions thereby allowing the incorporation of the peptide. Construct I was then 
layered with Col-I which thickened the diameter of the construct and resulted in the formation of larger fibrillar matrices. The FVC-Dsp-Col-I interaction is a result of the repeat sequence of Gly-Pro-Hyp which not only promotes the formation of triple helical collagen fibers, but also promotes interactions with the FVC-DSp composite via $\mathrm{CH}-\pi$ interactions due to the proline and hydroxyproline residues present in the collagen and aromatic Fmoc groups [88,89]. Furthermore, the charged residues in DSp (K, E, D, H) allow for strong electrostatic interactions between the FVC-DSp composite and Col-I [90]. When Ch was incorporated, the FVC-DSp-Col-I matrices were found to be covered with a thick, uniform film of $\mathrm{Ch}$. The ridges observed are consistent with the literature that indicates $\mathrm{Ch}$ uniformly attached to the FVC-DSp-Col-I matrices due to the presence of hydroxyl and amino groups that induce strong inter- and intra-molecular hydrogen bonding interactions with DSp [91]. Such films of chitosan have been shown to efficiently promote cell attachment, migration and growth [92]. CS was incorporated as the final layer, which was confirmed by the morphological change into thick mesh-like structures with distinct networks. The negatively charged carboxylate and sulfate groups present in CS allows for electrostatic interactions with free $\mathrm{NH}_{3}{ }^{+}$groups of $\mathrm{Ch}$ thereby promoting attachment to the FVC-DSp-Col-I-Ch matrices [93]. Additionally GAGs with high charge density such as CS have been shown to interact well with collagen and multiple interactions can be facilitated through CS chains [94]. Therefore, incorporation of CS is attributed to electrostatic interactions between negatively charged CS and positively charged $\mathrm{Ch}$ as well as with collagen.

To fabricate Construct II, the FVC template was first layered with CP (collagen II binding peptide sequence) (KLGFFAH) which resulted in the formation of self-assembled fibrillar structures wrapped around FVC templates and interlaced within a peptide matrix. It is likely that the presence of the FVC fibers enhanced the self-assembly of the short peptide sequence due to aromatic residues $(\mathrm{F}, \mathrm{F}, \mathrm{H})$ resulting in strong $\pi-\pi$ stacking interactions and cation- $\pi$ interactions due to the net positive charge of the $\mathrm{CP}$ sequence. Furthermore, it has been shown that short aromatic peptide sequences when conjugated to aromatic groups demonstrate compact volumes and reduce steric repulsion typically associated with long alkyl chains [95]. This is caused by the overlap of aromatic rings leading to plane-to-plane or edge-to-plane orientation, which leads to efficient assembly [96]. Incorporation of Col-II also induced morphological difference forming large fibrillar matrices [97]. The integration of Col-II with FVC-CP sequence was promoted primarily because the sequence is a conserved sequence found in the $\alpha-10$ integrin subunit of chondrocytes that aids in binding interactions with collagen II in cartilage tissue [57]. Col-II has been known to have strong interactions with proteoglycans and glycosaminoglycans resulting in gelatinous matrices [98]. As shown in the SEM results, upon incorporation of $\mathrm{Ch}$, we observed the formation of a gelatinous matrix. Finally, upon integration of CS, we observed thick mesh like structures, similar to those observed in the case of Col-I due to interactions described earlier. Therefore, the different structural morphologies between Constructs I and II can be explained by the different peptide and collagen components incorporated.

\subsection{FTIR Spectroscopy}

We further confirmed the incorporation of each layer involved in the formation of Constructs I and II by FTIR spectroscopy which showed distinct shifts for each layer of composite formed. Amide I absorption arises primarily from protein $\mathrm{C}=\mathrm{O}$ stretching vibrations whereas the amide II absorption is indicative of $\mathrm{N}-\mathrm{H}$ bending vibrations coupled with $\mathrm{C}-\mathrm{N}$ stretching vibrations and the amide III region is 
complexed due to $\mathrm{C}-\mathrm{N}$ stretching and $\mathrm{N}-\mathrm{H}$ in-plane bending from amide linkages as well as wagging vibrations [99]. The amide I band in particular $\left(1600-1700 \mathrm{~cm}^{-1}\right)$ involves $\mathrm{C}=\mathrm{O}$ stretches coupled with $\mathrm{N}-\mathrm{H}$ bending characterizing the secondary structure of peptide sequence [100]. Thus distinct changes observed in both constructs after assimilation of each layer not only confirm their incorporation, but also indicate the critical role that the amide group interactions play in binding each layer. Changes were also seen in the hydroxyl regions as explained in the results section particularly after incorporation of chitosan and chondroitin sulfate as these compounds are GAGs which form hydrogel matrices that can absorb large quantities of water and are characterized the presence of ample hydroxyl groups and - NH groups in the N-acetyl-glucosamine groups of chitosan and sulfated GAG of CS respectively.

\subsection{Differential Scanning Calorimetry}

DSC was conducted to examine thermal phase transitions in Construct I and Construct II [101]. The exothermic peak observed in Construct I at $8.8^{\circ} \mathrm{C}$ is attributed to the crystallization of bound water restricted by hydroxyl groups present in $\mathrm{CS}$ and $\mathrm{Ch}$ in the first order transition phase [102]. The endothermic peaks observed at $55^{\circ} \mathrm{C}$ and at $79^{\circ} \mathrm{C}$ are due to loss of free water that was not tightly bound to the matrices. The broad peak observed from 105 to $220^{\circ} \mathrm{C}$ can be considered as the re-evaporation into free state of bound water associated with the carboxylic groups in the construct [103]. It is well studied that higher temperature forces absorbed and firmly bound water into the free state outside of the influence of the construct matrix, allowing this state of free water to remain relatively constant [104]. The Construct II thermogram is shown in Figure 4b. Similar to Construct I, a sharp exothermic peak at $16.8{ }^{\circ} \mathrm{C}$ was observed indicating the crystallization of water. Two additional short endothermic peaks were also observed at 25 and $30{ }^{\circ} \mathrm{C}$ due to loss of unbound water. A very broad endothermic peak in the $107-225{ }^{\circ} \mathrm{C}$ region was again observed similar to Construct I, due to the loss of bound water from the gelatinous matrix. Similar results have been observed for collagen-GAG blends due to phase transitions and water loss thus confirming the formation of the constructs $[105,106]$.

\subsection{AFM Imaging and Nanoindentation Analysis}

The AFM images obtained further confirm the fibrous nature of the scaffolds with rough surfaces due to the multilayered structures incorporated with various peptide components and gelatinous chitosan and chondroitin sulfate. It is well known that the surface roughness and the mechanical properties of scaffolds influence cell-material interactions [107]. Upon examination of the surface roughness, it was found to be higher in the case of Construct II compared to Construct I, most likely due to differences in the mode of attachment of each layer for each of the constructs. Force-displacement curves were detected from various locations within the fibrous matrices to determine the nanomechanical properties of the constructs. As seen in the figures, the curves show similar decay characteristics, though the extents are different. This is likely due to the varied structural orientations locally within the matrices as a result of the multilayered structure. By extracting from the AFM images and nanoindentation curves, the results were applied to Hertzian model and the average Young's Modulus E was determined for each construct. The Young's modulus was found to be higher for Construct II $(551.3 \pm 1.3 \mathrm{kPa})$ in comparison to Construct I $(208.1 \pm 3.2 \mathrm{kPa})$ indicating that Construct II scaffolds are likely to have relatively higher stiffness, where as Construct I scaffolds have higher flexibility. In general, the Young's Modulus for fibrous 
matrices synthesized from PLGA as determined by nanoindentation methods has been found to be in the range of $\sim 50 \mathrm{kPa}$ [108]. Further it has also been reported that when chitosan is incorporated into polymer based scaffolds such as PEO, there is an increase in the Young's Modulus [109]. Polyacrylamide, polyethylene glycol as well as gels containing gelatin or hyaluronic acid have been shown to have Young's Modulus values in the range of $0.1 \mathrm{kPa}$ at the lower end to $100 \mathrm{kPa}$ at the higher end [110]. Most soft tissue structures in the body are more rigid compared to polymeric matrices, and their Young's Modulus values obtained by nanoindentation methods range from 0.6 to $4000 \mathrm{KPa}[111,112]$. Thus, the values obtained for Constructs I and II are within the range of the values obtained for soft tissues such as cartilage. It is to be noted that the values obtained are likely to increase in an extracellular matrix environment.

\subsection{Cell Morphology and Adhesion}

Optical microscopy as well as scanning electron microscopy was utilized to study the interactions of each of the constructs with bovine chondrocyte cells which were grown to confluency prior to the study. In general, we observed higher and faster adhesion with Construct II compared to Construct I. This may be due to the higher surface roughness of Construct II, which formed large 3D-cell-scaffold matrices uniformly spread while Construct I, although successful at attaching to the cells and inducing proliferation, showed a relatively slower and less overall formation of cell-scaffold matrices as compared to Construct II. As seen in the results within $72 \mathrm{~h}$, significant adhesion to Construct II with formation of large 3D matrices were observed, while after $96 \mathrm{~h}$ in the case of Construct I, comparably less adhesion was observed. In general, the cells maintained their spherical shapes, indicating that the scaffolds provided a stable matrix environment. After $72 \mathrm{~h}$, we observed increased adhesion to Construct II, while in the case of Construct I, no significant increase was observed after $144 \mathrm{~h}$ (data not shown). The enhanced adhesion of cells with Construct II is also likely because chondrocytes have a higher affinity for Col-II which was utilized as one of the components of Construct II. Col-II forms an integral part of elastic and hyaline cartilage tissues giving it elasticity and strength [113]. In addition, the presence of the CP peptide sequence which is normally present in chondrocytes and plays an integral role in cartilage formation and Col-II binding may also have resulted in higher affinity of the cells toward Construct II. Col-I and Col-II are both present in fibrocartilage and therefore Construct I may be more suitable for TE of intervertebral disc space, while Construct II may be more apt for hyaline or elastic cartilage TE [114]. Thus, our results indicate that both constructs provided stable matrices for cell proliferation, adhesion and growth and that the adhesion of the cells depended largely on the peptide composition.

To confirm cell proliferation with the constructs, MTT assays were performed and the absorbance at $570 \mathrm{~nm}$ was monitored. We observed an increase in the absorbance over time, which indicates higher amounts of live cells, corresponding to cell proliferation and viability. More gradual increase in cell viability over a three day period was observed for Construct II as compared to Construct I. Cell proliferation did occur, however, in both cases. The results suggest that cells proliferated relatively more favorably when a lower amount of Construct II was utilized. This is likely because cell binding occurs rapidly in the case of Construct II and the surfaces may get saturated with cells resulting in contact inhibition which slows down the proliferation [115]. Overall, the results show that Constructs I and II are highly biocompatible and encouraged cell proliferation. 


\subsection{Proteoglycan Synthesis}

Chondrogenesis is the process of forming cartilage intermediates, which in the body are naturally initiated by the differentiation of mesenchymal stem cells. The process begins with cell gathering, migration, and proliferation [104]. The aggregation of cells that occurs forms cartilage nodules [116]. The nodule aggregates begin forming components of the extracellular matrix, namely proteoglycans and sulfated proteoglycans, which can be observed experimentally by Alcian blue staining [117,118]. Our results indicated that both Construct I and Construct II successfully induced the formation of sulfated proteoglycans as shown by imaging studies conducted over a period of three weeks after Alcian blue assay. For Construct I, after seven days, few cells seemed to be aggregating together with minuscule formation of sulfated proteoglycans (data not shown). There was a noticeable increase in chondrocyte aggregation after 14 days and formation of sulfated proteoglycans for Construct I, while at 21 days, much higher amount of clusters and deeply stained blue aggregates were observed. For Construct II, we observed significantly higher aggregation and formation sulfated proteoglycans within seven days compared to those observed for Construct I which increased over time. By 21 days we observed proteoglycan formation throughout the surfaces as indicated by higher amounts of clusters and deeply stained blue aggregates. Sulfated GAG formation was slower in the case of Construct I and overall after 21 days we observed proteoglycan formation for both constructs, though higher formation occurred in the case of Construct II. Upon quantification, results indicated a four-fold increase in sulfated GAGs by 21 day period for the Construct II cell seeded scaffolds in comparison to Construct I, which showed a threefold increase. These results indicate that Construct II not only adheres to the cells more rapidly but also encourages GAG formation more significantly. Thus, both scaffolds support the formation of proteoglycans which is a key process during chondrogenesis and thus may have potential applications in cartilage TE, though Construct II demonstrated a relatively higher capability.

\subsection{Soluble Collagen Synthesis}

For quantitatively examining total soluble collagen synthesis in vitro cell culture studies in the presence of both constructs were carried out by sircol assay and were compared to results obtained for control chondrocyte cells. Our results indicate that the cell seeded scaffolds were capable of collagen production and there was a significant increase in collagen production after $96 \mathrm{~h}$ of culture. Further tests are needed to determine the exact proportions of Type I and Type II collagens and the gene expression of different types of collagens formed in the presence of the constructs. This would allow us to further determine the suitability of the constructs as implants for specific types of cartilage such as hyaline, fibrous or elastic cartilage.

\section{Conclusions}

We have developed two novel biomaterial constructs for potential applications in cartilage tissue regeneration. Constructs were assembled utilizing a FVC nanofiber template layer followed by integration with peptide sequences derived from dentin sialophosphoprotein and Type I collagen (Construct I) or collagen II binding peptide sequence derived from integrin binding region of chondrocytes followed by incorporation of Type II collagen (Construct II). Both constructs were then attached to chitosan and 
chondroitin sulfate. The morphology of the formed composite scaffolds was examined using SEM. FTIR spectroscopy further confirmed the incorporation of each consecutive layer. Assembly of the materials was largely driven by non-covalent interactions, such as hydrophobic interactions, $\pi-\pi$ stacking interactions between aromatic moieties present in the constructs in addition to electrostatic interactions between the peptides and the GAG moieties. Both Construct I and Construct II demonstrated thermal phase transitions due to loss of water, indicating their hydrogel properties. Both constructs were found to be biocompatible and adhered to chondrocyte cells as well as promoted proteoglycan synthesis. However, Construct II showed higher cell adhesion and increased proteoglycan and collagen synthesis, indicating that Construct II may have a better capacity as an implant for cartilage tissue regeneration compared to Construct I, though both are potentially suitable. Our results indicate that the peptide composition of the scaffolds plays an important role in chondrocyte cell adhesion, collagen synthesis and proteoglycan synthesis and thus in developing scaffolds for cartilage tissue regeneration.

\section{Acknowledgments}

The authors would like to thank Fordham University Research Grants for financial support of this work. Anthony M. Santora would like to acknowledge the CSTEP program at Fordham University for financial support. The authors also thank Pierre-Yves Blanchard for his help and assistance with the AFM experiments.

\section{Author Contributions}

Steven M. Romanelli carried out the synthesis and fabrication of Constructs I and II as well as SEM, DSC and FTIR studies. He was also responsible for writing the chemical and materials aspects of the manuscript. Grant A. Knoll was responsible for carrying out cells studies for Construct I, while Anthony M. Santora carried out all cell assays for Construct II and was also responsible for writing parts of cell studies. Alexandra M. Brown carried out some of the collagen assays. Ipsita A. Banerjee was responsible for all parts of the research project including writing the manuscript and overall supervision of the project.

\section{Conflicts of Interest}

The authors declare no conflict of interest.

\section{References}

1. Khademhosseini, A.; Vacanti, J.P.; Langer, R. Progress in tissue engineering. Sci. Am. 2009, 300, 64-71.

2. Healy, K.E.; Guldberg, R.E. Bone tissue engineering. J. Musculoskelet. Neuronal Interact. 2007, 7, 328-330.

3. Moreira-Teixeira, L.S.; Georgi, N.; Leijten, J.; Wu, L.; Karperien, M. Cartilage tissue engineering. Endocr. Dev. 2011, 21, 102-115.

4. Shi, J.; Votruba, A.R.; Farokhzad, O.C.; Langer, R. Nanotechnology in drug delivery and tissue engineering: From discovery to applications. Nano. Lett. 2010, 10, 3223-3230. 
5. Lipkin, R. Tissue engineering: Replacing damaged organs with new tissues. Sci. News 1995, 148, 24-26.

6. Huey, D.J.; Hu, J.C.; Athanasiou, K.A. Unlike bone, cartilage regeneration remains elusive. Science 2012, 338, 917-921.

7. Pullig, O.; Weseloh, G.; Klatt, A.R.; Wagener, R.; Swobda, B. Matrilin-3 in human articular cartilage: Increased expression in osteoarthritis. Osteoarthr. Cartil. 2002, 10, 253-263.

8. Buckwalter, J.A.; Mankin, H.J. Articular cartilage: Degeneration and osteoarthritis, repair, regeneration and transplantation. Instr. Course Lect. 1998, 47, 487-504.

9. Hjelle, K.; Solheim, E.; Strand, T.; Muri, R.; Brittberg, M. Articular cartilage defects in 1,000 knee arthroscopies. Arthrosc. J. Arthrosc. Relat. Surg. 2002, 18, 730-734.

10. Buckwalter, J.A.; Mankin, H.J. Articular cartilage: Tissue design and chondrocyte-matrix interactions. Instr. Course Lect. 1998, 47, 477-486.

11. Newman, A.P. Articular cartilage repair. Am. J. Sports Med. 1998, 26, 309-324.

12. Hunzinker, E.B. Articular cartilage repair: Basic science and clinical progress. A review on the current status and prospectives. Osteoarthr. Cartil. 2001, 10, 432-463.

13. Darling, E.M.; Athanasiou, K.A. Biomedical strategies for articular cartilage regeneration. Ann. Biomed. Eng. 2003, 31, 1114-1124.

14. Suh, J.K.; Matthew, H.W.T. Application of chitosan-based polysaccharide biomaterials in cartilage tissue engineering: A review. Biomaterials 2000, 21, 2589-2598.

15. Hutchmacher, D.W. Scaffolds in tissue engineering bone and cartilage. Biomaterials 2000, 21, 2529-2543.

16. Choi, B.; Kim, S.; Lin, B.; Wu, B.M.; Lee, M. Cartilaginous extracellular matrix-modified chitosan hydrogels for cartilage tissue engineering. ACS Appl. Mater. Interfaces 2014, 6, 20110-20121.

17. Van Vlierbergh, S.; Dubruel, P.; Schacht, E. Biopolymer-based hydrogels as scaffolds for tissue engineering applications: A review. Biomacromolecules 2011, 12, 1387-1408.

18. Yamaoka, H.; Asato, H.; Ogasawara, T.; Nishizawa, S.; Takahashi, T.; Nakatsuka, T.; Koshima, I.; Nakamura, K.; Kawaguchi, H.; Chung, U.; et al. Cartilage tissue engineering using human auricular chondrocytes embedded in different hydrogel materials. J. Biomed. Mater. Res. A 2006, 78, 1-11.

19. Chaipinyo, K.; Oakes, B.W.; Van Damme, M.P. The use of derbrided human articular cartilage for autologous chondrocyte implantation: Maintenance of chondrocyte differentiation and proliferation in type I collagen gels. J. Orthop. Res. 2004, 22, 446-455.

20. Kisiday, J.; Jin, M.; Kurz, B.; Hung, H.; Semino, C.; Zhang, S.; Grodzinsky, A.J. Self-assembling peptide hydrogel fosters chondrocyte extracellular matrix production and cell division: Implications for cartilage tissue repair. Proc. Natl. Acad. Sci. USA 2002, 99, 9996-10001.

21. Mart, R.J.; Osborne, R.D.; Stevens, M.M.; Ulijn, R.V. Peptide-based stimuli-responsive biomaterials. Soft Mater 2006, 2, 822-835.

22. Bryant, S.J.; Anseth, K.S. Controlling the spatial distribution of ECM components in degradable PEG hydrogels for tissue engineering cartilage. J. Biomed. Mater. Res. A 2003, 64, 70-79.

23. Drury, J.L.; Mooney, D.J. Hydrogels for tissue engineering: Scaffold design variables and applications. Biomaterials 2003, 24, 4337-4351. 
24. Noth, U.; Rackwitz, L.; Heymer, A.; Weber, M.; Baumann, B.; Steinhert, A.; Schutze, N.; Jakob, F.; Eulert, J. Chondrogenic differentiation of human mesenchymal stem cells in collagen type I hydrogels. J. Biomed. Mater. Res. A 2007, 83, 626-635.

25. Balakrishnan, B.; Banerjee, R. Biopolymer-based hydrogels for cartilage tissue engineering. Chem. Rev. 2011, 111, 4453-4474.

26. Nehrer, S.; Domayer, S.; Dorotka, R.; Schatz, K.; Bindreiter, U.; Kotz, R. Three-year clinical outcome after chondrocyte transplantation using a hyaluronan matrix for cartilage repair. Eur. J. Radiol. 2006, 57, 3-8.

27. Mattioli-Belmonte, M.; Gigante, A.; Muzzarelli, R.A.; Politano, R.; De Benedittis, A.; Specchia, N.; Buffa, A.; Biagani, G.; Greco, F. N,N-dicarboxymethyl chitosan as delivery agent for bone morphogenetic protein in the repair of articular cartilage. Med. Biol. Eng. Comput. 1999, 37, 130-134.

28. Fan, H.; Hu, Y.; Zhang, C.; Li, X.; Lv, R.; Qin, L.; Zhu, R. Cartilage regeneration using mesenchymal stem cells and a PLGA-gelatin/chondroitin/hyaluronate hybrid scaffold. Biomaterials 2006, 27, 4573-4580.

29. Lee, C.R.; Grad, S.; Gorna, K.; Gogolewski, S.; Goessl, A.; Alini, M. Fibrin-polyurethane composites for articular cartilage tissue engineering: A preliminary analysis. Tissue Eng. 2005, 11, 1562-1573.

30. Paramonov, S.E.; Jun, H.W.; Hargerink, J.D. Self-assembly of peptide-amphiphile nanofibers: The roles of hydrogen bonding and amphiphilic packing. J. Am. Chem. Soc. 2006, 128, 7291-7298.

31. Jun, H.W.; Paramonov, S.E.; Hartgerink, J.D. Biomimetic self-assembled nanofibers. Soft Matter 2006, 2, 177-181.

32. Slaughter, B.V.; Kurshid, S.S.; Fisher, O.Z.; Khademhosseini, A.; Peppas, N.A. Hydrogels in regenerative medicine. Adv. Mater 2009, 21, 3307-3329.

33. Shin, H.; Jo, S.; Mikos, A.G. Biomimetic materials for tissue engineering. Biomaterials 2003, 24, 4353-4364.

34. Hersel, U.; Dahmen, C.; Kessler, H. RGD modified polymers: Biomaterials for stimulated cell adhesion and beyond. Biomaterials 2003, 24, 4385-4415.

35. Ryan, D.M.; Nilsson, B.L. Self-assembled amino acids and dipeptides as non covalent hydrogels for tissue engineering. Polym. Chem. 2012, 3, 18-33.

36. Jayawarna, V.; Richardson, S.M.; Hirst, A.R.; Hodson, N.W.; Saiani, A.; Gough, J.E.; Ulijn, R.V. Introducing chemical functionality in Fmoc-peptide gels for cell culture. Acta Biomater. 2009, 5, 934-943.

37. Zhou, M.; Smith, A.M.; Das, A.K.; Hodson, N.W.; Collins, R.F.; Ulijn, R.V.; Gough, J.E. Self-assembled peptide-based hydrogels as scaffolds for anchorage-dependent cells. Biomaterials 2009, 30, 2523-2530.

38. Romanelli, S.M.; Hartnett, J.W.; Banerjee, I.A. Effects of amide side chains on nanoassembly formation and gelation of Fmoc-valine conjugates. Powder Technol. 2015, 271, 76-87.

39. Romanelli, S.M.; Fath, K.R.; Phekoo, A.P.; Knoll, G.A.; Banerjee, I.A. Layer-by-layer assembly of peptide based bioorganic-inorganic hybrid scaffolds and their interactions with osteoblastic MC3T3-E1 cells. Mater. Sci. Eng. C Mater. Biol. Appl. 2015, 51, 316-328. 
40. Qin, C.; Brunn, J.C.; Cadena, E.; Ridall, A.; Tsujigiwa, H.; Nagatsuka, H.; Nagai, N.; Butler, W.T. The expression of dentin sialophosphoprotein gene in bone. J. Dent. Res. 2002, 81, 392-394.

41. Ferré, F.C.; Larjava, H.; Loison-Robert, L.S.; Berbar, T.; Owen, G.R.; Berdal, A.; Cherafi, H.; Gogly, B.; Hakkinen, L.; Fournier, P.J.B. Formation of cartilage and synovial tissue by human gingival stem cells. Stem. Cells Dev. 2014, 23, 2895-2906.

42. Liu, Q; Gibson, M.P.; Sun, H.; Qin, C. Dentin sialophosphoprotein (DSPP) plays an essential role in postnatal development and maintenance of mouse mandibular condylar cartilage. J. Histochem. Cytochem. 2013, 61, 749-758.

43. Choi, Y.S.; Lee, J.Y.; Suh, J.S.; Lee, G.; Chung, C.P.; Park, Y.J. The mineralization inducing peptide derived from dentin sialophosphoprotein for bone regeneration. J. Biomed. Mater. Res. 2013, 101A, 590-598.

44. Yagihashi, K.; Miyazawa, K.; Togari, K.; Goto, S. Demineralized dentin matrix acts as a scaffold for repair of articular cartilage defects. Calcif. Tissue Int. 2009, 84, 210-220.

45. Fisher, L.W.; Tochia, D.A.; Fohr, B.; Young, M.F.; Fedarko, N.S.; Flexible structures of SIBLING proteins, bone sialophosphortein and osteopontin. Biochem. Biophys. Res. Commun. 2001, 280, $460-465$.

46. Prasad, M.; Zhu, Q.; Sun, Y.; Wang, X.; Kulkarni, A.; Boskey, A.; Feng, J.Q.; Qin, C. Expression of dentin sialophosphoprotein in non-mineralized tissues. J. Histochem. Cytochem. 2011, 59, 1009-1021.

47. Ramadass, S.K.; Perumal, S.; Gopinath, A.; Nisal, A.; Subramanjan, S.; Madhan, B. Sol-gel assisted fabrication of collagen hydrolysate composite scaffold: A novel therapeutic alternative to the traditional collagen scaffold. ACS Appl. Mater. Interfaces 2014, 6, 15015-15025.

48. Eyre, D.R.; Muir, H. Quantitative analysis of types I and II collagen in human intervertebral discs at various ages. Biochim. Biophys. Acta 1977, 492, 29-42.

49. Hong, Y.; Song, H.; Gong, Y.; Mao, Z.; Gao, C.; Shen, J. Covalently crosslinked chitosan hydrogel: Properties of in vitro degradation and chondrocyte encapsulation. Acta Biomater. 2007, 3, 23-31.

50. Prydz, K.; Dalen, K.T. Synthesis and sorting of proteoglycans. J. Cell Sci. 2000, 113, 193-205.

51. Di Martino, A.; Sittinger, M.; Risbud, M.V. Chitosan: A versatile biopolymer for orthapaedic tissue-engineering. Biomaterials 2005, 26, 5983-5990.

52. Jerosch, J. Effects of glucosamine and chondroitin sulfate on cartilage metabolism in OA: Outlook on other nutrient partners especially omega-3-fatty acids. Int. J. Rheumatol. 2011, 2011, 1-17.

53. Wei, J.; Wang, J.; Su, S.; Wang, E.; Qiu, J. Tough and fully cyclic recoverable biomimetic hydrogels. J. Mater. Chem. B 2015, 3, 5284-5290.

54. Lipiello, L. Glucosamine and chondroitin sulfate: Biological response modifiers of chondrocytes under simualted conditions of joint stress. Osteoarthr. Cartil. 2003, 11, 335-342.

55. Uebelhart, D.; Thonar, E.; Zhang, J.; Williams, J.M. Protective effect of exogenous chondroitin 4,6-sulfate in the acute degradation of articular cartilage in the rabbit. Osteoarthr. Cartil. 1998, 6, $6-13$.

56. Sechriest, V.F.; Miao, Y.J.; Niyibizi, C.; Westerhausen-Larson, A.; Matthew, H.W.; Evans, C.H.; Fuh, F.H.; Suh, J.K. GAG-augmented polysaccharide hydrogel: A novel biocompatible and biodegradable material to support chondrogenesis. J. Biomed. Mater. Res. 2000, 49, 534-541. 
57. Camper, L.; Hellman, U.; Lundgren-Akerlund, E. Isolation, cloning and sequence analysis of the integrin subunit $\alpha 10$, a $\beta 1$-assocaited collagen binding integrin expressed on chondrocytes. J. Biol. Chem. 1998, 273, 20383-20389.

58. Eyre, D.R.; Weis, M.A.; Wu, J.J. Articular cartilage collagen: An irreplaceable framework? Eur. Cells Mater. 2006, 12, 57-63.

59. Wachsmuth, L.; Soder, S.; Fan, Z.; Finger, F; Aigner, T. Immunolocalization of matrix proteins in different cartilage subtypes. Histo. Histopathol. 2006, 21, 477-485.

60. Billinghurst, R.C.; Dahlberg, L.; Ionescu, M.; Reiner, A.; Bourne, R.; Rorabeck, C.; Mitchell, P.; Hambor, J.; Diekmann, O.; Tschesche, H.; et al. Enhanced cleavage of type II collagen by collagenases in osteoarthritic articular cartilage. J. Clin. Investig. 1997, 99, 1534-1545.

61. Nehrer, S.; Breinan, H.A.; Ramappa, A.; Shortkroff, S.; Young, G.; Minas, T.; Sledge, C.B.; Yannas, I.V.; Spector, M. Canine chondrocytes seeded in type I and type II collagen implants investigated in vitro. J. Biomed. Mater. Res. 1997, 38, 95-104.

62. Bosnakovski, D.; Mizuno, M.; Kim, G.; Takagi, S.; Okumura, M.; Fujinaga, T. Chondrogenic differentiation of bovine bone marrow mesenchymal stem cells (MSCs) in different hydrogels: Influence of collagen type II extracellular matrix on MSC chondrogenesis. Biotechnol. Bioeng. 2006, 93, 1152-1163.

63. Hertz, H. Uber die beruhring fester elastischer korper. Reine Angew. Math. 1882, 92, 156-171.

64. Sneddon, I.N. The relation between load and penetration in the axisymmetric boussinesq problem for a punch of arbitrary profile. Int. J. Eng. Sci. 1965, 3, 47-57.

65. Matsui, Y.; Sugiyama, K.; Kamei, M.; Takahashi, T.; Suzuki, T.; Katagata, Y. Ito Extraction of passion fruit (Passiflora edulis) seed containing high amounts of picetannol inhibits melanogenesis and promotes collagen synthesis. J. Agric. Food Chem. 2010, 58, 11112-11118.

66. Vesentini, S.; Redaelli, A.; Gautieri, A. Nanomechanics of collagen microfibrils. Muscle Ligaments Tendons J. 2013, 3, 23-34.

67. Zandomeneghi, G.; Krebs, M.R.H.; McCammon, M.G.; Fändrich, M. FTIR reveals structural differences between native $\beta$-sheet proteins and amyloid fibers. Protein Sci. 2004, 13, 3314-3321.

68. Susi, H.; Byler, D.M. Fourier transform infrared study of proteins with parallel $\beta$-chains. Arch. Biochem. Biophys. 1987, 258, 465-469.

69. Khodzhaeva, V.L. Study of liquid crystalline state of p-n-alkyloxybenzoic acids according to their IR absorption spectra. Bull. Acad. Sci. USSR 1969, 18, 2257-2262.

70. Konshina, E.A.; Vangonen, A.I. Features of the vibrational spectra of diamond-like and polymer-like a C:H films. Semiconductors 2005, 39, 585-590.

71. Parkih, S.J.; Kubicki, J.D.; Jonsson, C.M.; Jonsson, C.L.; Hazen, R.M.; Sverjensky, D.A.; Sparks, D.L. Evaluating glutamate and aspartate binding mechanisms to rutile $\left(\alpha-\mathrm{TiO}_{2}\right)$ via ATR-FTIR spectroscopy and quantum chemical calculations. Langmuir 2011, 27, 1778-1787.

72. Belbachir, K.; Noreen, R.; Gouspillou, G.; Petibois, C. Collagen types analysis and differentiation by FTIR spectroscopy. Anal. Bioanal. Chem. 2009, 395, 829-837.

73. Vitagliano, L.; Berisio, R.; Mazzarella, L.; Zagari, A. Structural basis of collagen stabilization induced by proline hydroxylation. Biopolymers 2001, 58, 459-464.

74. Sedaghat, S. Synthesis and characterization of new biocompatible copolymer: Chitosan-graft polyaniline. Int. Nano Lett. 2014, 4, doi:10.1186/2228-5326-4-2. 
75. Mucha, M.; Piekielna, J.; Wieczorek, A. Characterization and morphology of biodegradable chitosan/synthetic polymer blends. Macromol. Symp. 1999, 144, 391-412.

76. Kolhe, P.; Kannan, R.M. Improvement in ductility of chitosan through blending and copolymerization with PEG: FTIR investigation of molecular interactions. Biomacromolecules 2003, 4, 173-180.

77. Chen, A.L.; Ni, H.C.; Wang, L.F.; Chen, J.S. Biodegradable amphiphilic copolymers based on poly(e-caprolactone)-graft chondroitin sulfate as drug carriers. Biomacromolecules 2009, 9, 2477-2457.

78. Hanifi, A.; McCarthy, H.; Roberts, S.; Pleshko, N. Fourier transform infrared imaging and infrared fiber optic probe spectroscopy identify collagen type in connective tissues. PLOS ONE 2013, 8, doi:10.1371/journal.pone.0064822.

79. Gargiulo, B.J.; Cragg, P.; Richardson, J.B.; Ashton, B.A.; Johnson, W.E.B. Phenotypic modulation of human articular chondrocytes by bistratene A. Eur. Cells. Mater. 2002, 3, 9-18.

80. Joyce, M.E.; Roberts, A.B.; Sporn, M.B.; Bolander, M.E. Transforming Growth Factor-beta and the Initiation of Chondrogenesis and Osteogenesis in the Rat Femur. J. Cell Biol. 1990, 110, 2195-2207.

81. Kadler, K.E.; Baldock, C.; Bella, J.; Boot-Handford, R.P. Collagens at a glance. J. Cell Sci. 2007, 120, 1955-1958.

82. Orbach, R.; Adler-Abramovich, L.; Zigerson, S.; Mironi-Harpaz, I.; Seliktar, D.; Gazit, E. Self-assembled Fmoc-peptides as a platform for the formation of nanostructures and hydrogels. Biomacromolecules 2009, 10, 2646-2651.

83. Javid, N.; Roy, S.; Zelzer, M.; Yang, Z.; Sefcik, J.; Ulijn, R.V. Cooperative self-assembly of peptide gelators and proteins. Biomacromolecules 2013, 14, 4368-4376.

84. Subramanian, M.; Sheshadri, B.S.; Vekatappa, M.P. Interactions of proteins with detergents: Binding of cationic detergents with lysozyme. J. Biosci. 1986, 10, 359-371.

85. Nakayaka, K.; Ushiwata, A.; Nakamura, Y. Interaction between proteins and detergents which contain a hydrocarbon chain longer than 16 carbon atoms. III. Competitive inhibition of trypsin by cetyldimethylbenzylammonium chloride. Biochim. Biophys. Acta 1976, 439, 116-124.

86. Xie, Y.; Wang, X.; Huang, R.; Qi, W.; Wang, Y.; Su, R.; He, Z. Electrostatic and aromatic interaction-directed supramolecular self-assembly of a designed Fmoc-tripeptide into helican ribbons. Langmuir 2015, 31, 2885-2894.

87. Tang, C.; Ulijn, R.; Saiani, A. Self-assembly and gelation properties of glycine/leucine Fmoc-dipeptides. Eur. Phys. J. E 2013, 36, 1-11.

88. Riley, G.P.; Harrall, R.L.; Constant, C.R.; Chard, M.D.; Cawston, T.E.; Hazleman, B.L. Glycosaminoglycans of human rotator cuff tendons: Changes with age and in chronic rotator cuff tendonitis. Ann. Rheum. Dis. 1994, 53, 367-376.

89. Zondlo, N.J. Aromatic-proline interactions: Electronically tunable $\mathrm{CH} / \pi$ interactions. Acc. Chem. Res. 2013, 46, 1039-1049.

90. Kar, K.; Wang, Y.H.; Brodsky, B. Sequence dependence of kinetics and morphology of collagen model peptide self-assembly into higher order structures. Protein Sci. 2008, 17, 1086-1095.

91. Gong, J.; Zhou, Z.; Hu, X.; Wong, M.K.; Du, Z. Self-assembled chitosan nanotemplates for biomineralization of controlled calcite nanoarchitectures. Appl. Mater. Inter. 2009, 1, 26-29. 
92. Hamilton, V.; Yuan, Y.; Rigney, D.A.; Puckett, A.D.; Ong, J.L.; Yang, Y.; Elder, S.H.; Bumgardner, J.D. Characterization of chitosan films and effects on fibroblast cell attachment and proliferation. J. Mater. Sci. Med. 2006, 17, 1373-1381.

93. Kuijpers, A.J.; Engbers, G.H.M.; Meyvis, T.K.L.; de Smedt, S.S.C.; Demeester, J.; Krijgsveld, J.; Zaat, S.A.J.; Dankert, J.; Feijen, J. Combined gelatin-chondroitin sulfate hydrogels for controlled release of cationic antibacterial proteins. Macromolecules 2000, 33, 3705-3713.

94. Oldber, A.; Ruoslahti, E. Interactions between chondroitin sulfate proteoglycan, fibronectin and collagen. J. Biol. Chem. 1982, 257, 4859-4863.

95. Ma, M.; Kuang, Y.; Gao, Y.; Zhang, Y.; Gao, P.; Xu, B. Aromatic-aromatic interactions induce the self-assembly of pentapeptidic derivatives in water to form nanofibers and supramolecular hydrogels. J. Am. Chem. Soc. 2010, 132, 2719-2728.

96. Burley, S.K.; Petsko, G.A. Aromatic-aromatic interaction: A mechanism of protein structure stabilization. Science 1985, 229, 23-28.

97. Hulmes, D.J.S. Building collagen molecules, fibrils and suprafibrillar structures. J. Struct. Biol. 2002, 137, 2-10.

98. Fertala, A.; Sieron, A.L.; Hojima, Y.; Ganguly, A.; Prockop, D.J. Self-assembly into fibrils of collagen II by enzymic cleavage of recombinant procollagen II. J. Biol. Chem. 1994, 269, 11584-11589.

99. Piez, K.A. Primary Structure. In Biochemistry of Collagen; Ramachandran, G.N., Reddi, A.H., Eds.; Plenum Press: New York, NY, USA, 1976; pp. 1-44.

100. Jackson, M.; Choo, L.P.; Watson, P.H.; Halliday, W.C.; Mantsch, H.H. Beware of connective tissue proteins: Assignment and implications of collagen absorptions in infrared spectra of human tissues. Biochim. Biophys. Acta 1995, 1270, 1-6.

101. McClain, P.E.; Wiley, E.R. Differential scanning calorimeter studies of the thermal transitions of collagen. J. Biol. Chem. 1972, 247, 692-697.

102. Nakmura, K.; Hatakeyama, T.; Hatakeyama, H. Studies on bound water of cellulose by differential scanning calorimetry. Text. Res. J. 1981, 51, 607-613.

103. Kittur, F.S.; Prashanth, K.V.H.; Sankar, K.U.; Tharanathan, R.N. Characterization of chitin, chitosan and their carboxymethyl derivatives by differential scanning calorimetry. Carbohydr. Polym. 2002, 49, 185-193.

104. Kacurakova, M.; Belton, P.S.; Wilson, R.H.; Hirsch, J.; Ebringerova, A. Hydration properties of xylan-type structures: An FTIR study of xylooligosaccharides. J. Sci. Food Agric. 1998, 77, 38-44.

105. Shanmugasundaram, N.; Ravichandran, P.; Reddy, P.N.; Ramamurthy, N.; Pal, S.; Rao, K.P. Collagen-chitosan polymeric scaffolds for in vitro culture of human epidermoid carcinoma cells. Biomaterials 2001, 22, 1943-1951.

106. Yang, H.Y.; Zhang, Q.Q. Preparation and characterization of collagen-GAG bioactive matrices for tissue engineering J. Mater. Sci. Technol. 2001, 17, 495-500.

107. Engler, A.J.; Sen, S.; Sweeney, H.L.; Discher, D.E. Matrix elasticity directs stem cell lineage specification. Cell 2006, 126, 677-689. 
108. Xin, X.; Hussain, M.; Mao, J.J. Continuing differentiation of human mesenchymal stem cells and induced chondrogenic and osteogenic lineages in electrospun PLGA nanofiber scaffold. Biomaterials 2007, 28, 316-325.

109. Djokic, J.D.; Kojovic, A.; Stojanovic, D.; Marinkovic, A.; Vukovic, G.; Aleksic, R.; Uskokovic, P.S. Processing and Nanomechanical properties of chitosan/poly (ethylene oxide) blend films. J. Serb. Chem. Soc. 2012, 77, 1723-1733.

110. Palchesko, R.N.; Zhang, L.; Sun, Y.; Feinberg, A.W. Development of Polydimethylsiloxane substrates with tunable elastic modulus to study cell mechanobiology in muscle and nerve. PLoS ONE 2012, 7, doi:10.1371/journal.pone.0051499.

111. Candiello, J.; Balasubramani, M.; Schreiber, E.M.; Cole, G.J.; Mayer, U.; Halfter, W.; Lin, H. Biomechanical properties of native basement membranes. FEBS J. 2007, 274, 2897-2908.

112. Constantinides, G.; Kalcioglu, Z.I.; McFarland, M.; Smith, J.F.; Van Vliet, K.J. Probing mechanical properties of fully hydrated gels and biological tissues. J. Biomech. 2008, 41, 3285-3289.

113. Ko, C.S.; Wu, C.H.; Huang, H.H.; Chu, I.M. Genipin cross-linking of type II collagen-chondroitin sulfate-hyaluronan scaffold for articular cartilage therapy. J. Med. Biol. Eng. 2007, 27, 7-14.

114. Nesti, L.J.; Li, W.J.; Shanti, R.M.; Jiang, Y.J.; Jackson, W.; Freedman, B.A.; Kuklo, T.R.; Giuliani, J.R.; Tuan, R.S. Intervertebral disc tissue engineering using a novel hyaluronic acid-nanofibrous scaffold (HANFS) amalgam. Tissue Eng. A 2008, 14, 1527-1537.

115. Cherry, R.S.; Papoutsakis, E.T. Modeling of contact-inhibited animal cell growth on flat surfaces and spheres. Biotechnol. Bioeng. 1989, 33, 300-305.

116. Goldring, M.B.; Tsuchimochi, K.; Ijuru, K. The Control of Chondrogenesis. J. Cell. Biochem. 2006, 97, 33-44.

117. Ahrens, P.B.; Solurush, M.; Reiter, R.S. Stage-related capacity for limb chondrogenesis in cell culture. Dev. Biol. 1977, 60, 69-82.

118. Hassell, J.R.; Horigan, E.A.; Chondrogenesis: A model developmental system for measuring teratogenic potential of compounds. Teratog. Carcinog. Mutagen. 1982, 2, 325-331.

(C) 2015 by the authors; licensee MDPI, Basel, Switzerland. This article is an open access article distributed under the terms and conditions of the Creative Commons Attribution license (http://creativecommons.org/licenses/by/4.0/). 